\title{
The effects of gypsum on the transfer of phosphorus and other nutrients through clay soil monoliths
}

\author{
Risto Uusitalo ${ }^{1}$, Kari Ylivainio ${ }^{1}$, Jari Hyväluoma ${ }^{1}$, Kimmo Rasa ${ }^{1}$, Janne Kaseva ${ }^{1}$, Pauliina Nylund ${ }^{1}$, Liisa Pietola ${ }^{2,3}$ \\ and Eila Turtola ${ }^{1}$ \\ ${ }^{1}$ MTT Agrifood Research Finland, Plant Production Research, Fl-31600 Jokioinen \\ ${ }^{2}$ Yara Suomi Oy, Mechelininkatu 1a, P.O.Box 900, FI-00181 Helsinki \\ ${ }^{3}$ Present address: MTK (Central Union of Agricultural Producers and Forest Owners), PL 510, FI-00101 Helsinki \\ e-mail: risto.uusitalo@mtt.fi
}

\begin{abstract}
We applied gypsum $\left(\mathrm{CaSO}_{4} \times 2 \mathrm{H}_{2} \mathrm{O}\right.$ ) amendments to $100 \mathrm{~m}^{2}$ plots within two clay-textured fields, one under shallow cultivation to $10 \mathrm{~cm}$ depth and the other ploughed to $20 \mathrm{~cm}$ depth. Unamended plots and plots subjected to a $\mathrm{CaCO}_{3}$ (finely ground limestone) application served as controls. Separate soil monoliths $(30 \mathrm{~cm}$ in diameter, $40 \mathrm{~cm}$ in depth) were collected for laboratory rainfall simulations from all plots 7, 19 and 31 months after the initial application of the amendments. Water passed through the monoliths during these simulations was analysed for turbidity, dissolved and particulate phosphorus (DRP and PP), nitrogen species, dissolved organic carbon (DOC), as well as dissolved $\mathrm{Ca}^{2+}, \mathrm{Mg}^{2+}, \mathrm{K}^{+}$and $\mathrm{S}, \mathrm{pH}$, and electrical conductivity (EC). Over the three-year monitoring period, gypsum amended soils exhibited substantial decreases in turbidity (45\%), PP (70\%), DRP (50\%) and DOC (35\%) relative to control samples. The effects gradually decreased with time, and after 31 months gypsum effects on P species were detectible, but no longer statistically significant. We consider gypsum amendments as a potential tool for slowing $\mathrm{P}$ loss from agricultural areas with high $\mathrm{P}$ loss potential.
\end{abstract}

Key words: Gypsum, erosion, phosphorus, carbon, nitrogen, leaching, percolation, rainfall simulation, subsurface drainage, agricultural water protection

\section{Introduction}

In addition to being a source of $\mathrm{Ca}$ and $\mathrm{S}$ nutrients for cultivated plants, the mineral gypsum $\left(\mathrm{CaSO}_{4} \times 2 \mathrm{H}_{2} \mathrm{O}\right)$ has been found to enhance water infiltration in poorly structured soils, inhibit the formation of surface crusts and alleviate the effects of excessive soil acidity that may restrict root development (see Shainberg et al., 1989). Earlier studies on the use of gypsum in soil and water conservation projects have mostly focused on erosion (e.g., Warrington et al., 1989; Miller, 1987), whereas recent studies have begun to address suppressing phosphorus solubility in high-P soils, and dissolved P (DRP) losses to runoff and percolation water (Zhu and Alva 1994, Stout et al. 2000, Cox et al. 2005). DRP loss abatement and erosion control are especially relevant to non-calcareous and high-P clay soils where unstable clay aggregates can disintegrate and release particles into runoff and percolation water. The dispersed particles represent a relatively large and reactive specific surface area, usually contain more $P$ than the source soil, and can be transported and deposited over large areas, and thus have the potential to contaminate surface waters with agrochemicals and nutrients.

Clay colloids interact according to a set of primary attractive and repulsive forces (see Ryan and Elimelech 1996, Grasso et al. 2002). These interactions are described by the widely used DLVO theory, although other so called 'non-DLVO' forces may also affect colloid behaviour (see Grasso et al. 2002). DLVO theory states that clay colloid interactions consist of attractive London-van der Waals forces arising from dipole-dipole interactions, and repulsive electrostatic double-layer forces acting between the negatively charged particles and their surrounding ionic halos. Coagulation or dispersion results from predominance of respective attractive or repulsive forces, as well as from the relative magnitudes of these forces.

Attractive London-van der Waals forces are generally assumed to be independent of changes in the chemical environment but the electrostatic repulsion can be influenced by the ionic strength and composition of a given solution (Ryan and Elimelech 1996, Grasso et al. 2002). Through the influence on the properties of the soil solution gypsum applications can exert primary effects on particle aggregation. Introduction of gypsum to a soil specifically diminishes repulsive forces by compressing the diffuse double layer at the particle surfaces, thus creating a smaller inter-particle repulsion maximum and shorter distance between individual particles. As a result, the relative importance of the attractive forces increases, enhancing colloid aggregation. 
In addition to the effect on colloid aggregation, gypsum may influence the specific adsorption of $\mathrm{P}$ onto metal hydroxide surfaces and edge-positions of silicate minerals by a mechanism similar to that described above for colloid aggregation. In the case of adsorption, compression of the diffuse double layer allows shorter distance between negatively charged mineral surfaces and anions, and thereby increases the rate of $\mathrm{P}$ adsorption (see Ryden and Syers 1975, Bar-Yosef et al. 1988). Gypsum as a source of $\mathrm{Ca}^{2+}$ may also exert electrolytic effects even if the overall ionic strength of the soil solution remains constant. Comparisons between soils saturated with divalent and monovalent ions (e.g., $\mathrm{Ca}^{2+}$ vs. $\mathrm{K}^{+}$) show that at constant ionic strength, high $\mathrm{Ca}^{2+}$ concentration in the solution increases $\mathrm{P}$ retention (Ryden and Syers, 1975). In some circumstances this effect may be partly due to $\mathrm{P}$ precipitation as Ca-P complexes (e.g. Zhu and Alva 1994).

Laboratory incubations have shown that gypsum can lower the proportion of water-soluble $\mathrm{P}$ in soils with low $\mathrm{P}$ retention capacity. Anderson et al. (1995) describe incubation experiments on manure-impacted soils from the Lake Okeechobee area (Florida, USA) in which gypsum caused a 40-63\% decrease in P solubility. Short-term incubations of gypsum amended soils showed a similar decrease in P solubility as that reported by O'Connor et al. (2005). Zhu and Alva (1994) found that gypsum amendments decreased P leaching from loamy sand soil columns by $20-49 \%$. Coale et al. (1994) observed an about $25 \%$ decrease in total dissolved P concentration in leachate resulting from a gypsum amendment to an Everglades Histosol (muck). O'Connor et al. (2005) found that a gypsum amendment applied to a packed column of sandy soil from the Lake Okeechobee area apparently lowered $P$ leaching by $33 \%$ relative to that observed for the unamended control. These workers further concluded that the relatively high solubility of gypsum made it more effective than water treatment residuals (WWTR's) containing $\mathrm{Al}$ or $\mathrm{Fe}$; the Al/Fe-WWTR's exhibited only localized effects in retaining and demobilizing P from those parts of the soil column in which they were mixed.

Results from rainfall simulation studies of $\mathrm{P}$ retention in gypsum amended soils have varied more widely than those of incubation and column leaching experiments. In their study of grass covered soils from central Pennsylvania, Stout et al. (2000) found that gypsum amendments reduced the dissolved $\mathrm{P}$ concentrations in runoff by $33 \%$, given 30 minutes of simulated rainfall at an intensity of $50 \mathrm{~mm} \mathrm{~h}^{-1}$. Gypsum amendments did not reduce particulate $\mathrm{P}$ (PP) detachment from soils having no plant cover and PP was the primary form of phosphorus transferred from the soil into runoff water (Stout et al. 2000). O'Connor et al. (2005) studied the effect of simulated rainstorms (intensity of $71 \mathrm{~mm} \mathrm{~h}^{-1}$ ) on sandy soils from Florida and found that gypsum amendments did not reduce $\mathrm{P}$ concentrations in surface runoff from bare or grass sod-covered soil. However, the gypsum application $\left(10 \mathrm{~g} \mathrm{~kg}^{-1}\right)$ apparently reduced dissolved $\mathrm{P}$ concentrations in water passed through a $7.5 \mathrm{~cm}$ soil layer packed into runoff boxes. Favaretto et al. (2006) conducted sequential rainfall simulation experiments (90 min at $30 \mathrm{~mm} \mathrm{~h}^{-1}$, followed by $30 \mathrm{~min}$ at $60 \mathrm{~mm} \mathrm{~h}^{-1}$ intensity) on silty loam soils from the Miami area. These workers found that gypsum amendments increased infiltration of water by $150 \%$ and decreased runoff by about $20 \%$ relative to the unamended control. Runoff from gypsum amended soils exhibited significantly lower DRP concentrations but overall sediment concentrations were similar to those found in runoff from the control group. Favaretto et al. (2006) also measured nitrogen species in runoff and found that $\mathrm{NO}_{3}-\mathrm{N}$ concentrations were similar for both the gypsum amended and unamended control treatments. Concentrations of $\mathrm{NH}_{4}-\mathrm{N}$ and particulate $\mathrm{N}$ however were lower in runoff from the gypsum amended soils relative to runoff from the control soils.

Rainfall simulation studies referred to above have thus yielded inconsistent results concerning the effects of gypsum on $\mathrm{P}$ transport, especially for PP. The high rain intensity used in many rainfall simulations (e.g., Stout et al. 2000, O'Connor et al. 2005, Favaretto et al. 2006) probably strongly influence the results of these studies, as the impact of raindrops on soil surface and rapid dilution of the soil solution abruptly change the physiochemical environment where P mobilization occurs. Even in cases where the experimental setup accurately simulates processes taking place in areas of high rainfall intensity, translating the results of these studies to regions with low intensity rains such as Finland introduces a significant degree of uncertainty.

This paper describes a series of rainfall simulation experiments designed to investigate the effects of gypsum amendments on percolation water quality on non-calcareous agricultural soils in southern Finland. This study was conducted in tandem with water quality monitoring of a catchment outlet (Ekholm et al. 2012) as well as catchment-scale modelling of effects of gypsum amendments on soil P losses (Jaakkola et al. 2012), and an economic evaluation of the use of gypsum in P-loss abatement (Iho and Laukkanen 2012).

The primary focus of this paper is to evaluate the efficacy of gypsum $\left(\mathrm{CaSO}_{4} \times 2 \mathrm{H}_{2} \mathrm{O}\right)$ amendments in reducing particle transport as well as nutrient (especially $\mathrm{P}$, but also $\mathrm{N}$ and macronutrient cations) and DOC loss from sub- 
drained clay soils that are annually tilled. Ploughing and other cultivation tillage conducted during the fall are the primary means of agricultural soil preparation in Finland. These tilled, fine-grained soils have a high P-loss potential, especially in the form of PP. The fine-grained soils require adequate subsurface drainage to allow field operations (without severe compaction of the soil) during spring and autumn. The majority of soil erosion and nutrient loss from these types of soils occurs through drainflow (see Turtola et al. 2007). Our experiments sought to assess the effects of gypsum amendments on drainflow water quality. We assumed that water percolating through undisturbed soil monoliths collected at $40 \mathrm{~cm}$ depth was compositionally equivalent to discharge via subsurface drainage pipes. The specific questions addressed by this research are as follows:

1. How much do moderate gypsum applications reduce $P$ transfer through undisturbed clay soils found in the study area?

2. How long do potential P-mitigation effects last and what proxies could be used to monitor the effective lifetime of a single gypsum application?

3. What effects do the gypsum amendments exert on the mobilization and leaching of other essential plant nutrients and DOC?

\section{Material and methods}

\section{Field sites}

The study area consisted of two fields located within a few kilometres of each other at Jokioinen, SW Finland. These sites are referred to as Fields 1 and 2 and were selected due to their relatively uniform soil texture in about a $100 \times 20 \mathrm{~m}$ layout, to allow designation of $12-16$ contiguous $5 \times 20 \mathrm{~m}$ plots. The soils at both field sites are classified as Vertic Cambisols (IUSS Working Group WRB, 2006) with clayey texture (Table 1).

Table 1. Particle size distribution and carbon content of the Ap horizon $(0-25 \mathrm{~cm})$ and the underlying soil layer $(25-40 \mathrm{~cm})$ from the two field sites investigated in this study. Results are given as mean values with the range in parentheses.

\begin{tabular}{|c|c|c|c|c|c|c|c|c|}
\hline & \multicolumn{7}{|c|}{ Particle size distribution (\%) } & \multirow[t]{2}{*}{ C (\%) } \\
\hline & $<0.002$ & -0.005 & -0.02 & -0.05 & -0.2 & -0.5 & $-2 \mathrm{~mm}$ & \\
\hline \multicolumn{9}{|c|}{ Field 1 (autumn cultivation to $10 \mathrm{~cm}$ depth), $\mathrm{n}=10$} \\
\hline $0-25 \mathrm{~cm}$ & $\begin{array}{l}49 \\
(41-56)\end{array}$ & $\begin{array}{l}12 \\
(10-13)\end{array}$ & $\begin{array}{l}12 \\
(10-14)\end{array}$ & $\begin{array}{l}16 \\
(11-22)\end{array}$ & $\begin{array}{l}5 \\
(4-8)\end{array}$ & $\begin{array}{l}4 \\
(3-5)\end{array}$ & $\begin{array}{l}3 \\
(2-4)\end{array}$ & $\begin{array}{l}1.8 \\
(1.5-2.2)\end{array}$ \\
\hline $25-40 \mathrm{~cm}$ & $\begin{array}{l}61 \\
(44-78)\end{array}$ & $\begin{array}{l}9 \\
(7-12)\end{array}$ & $\begin{array}{l}9 \\
(4-12)\end{array}$ & $\begin{array}{l}14 \\
(6-22)\end{array}$ & $\begin{array}{l}4 \\
(2-7)\end{array}$ & $\begin{array}{l}1 \\
(1-2)\end{array}$ & $\begin{array}{l}1 \\
(<1-3)\end{array}$ & $\begin{array}{l}0.5 \\
(0.4-0.7)\end{array}$ \\
\hline \multicolumn{9}{|c|}{ Field 2 (autumn ploughing to $20 \mathrm{~cm}$ depth), $\mathrm{n}=8$} \\
\hline $0-25 \mathrm{~cm}$ & $\begin{array}{l}55 \\
(52-57)\end{array}$ & $\begin{array}{l}18 \\
(17-18)\end{array}$ & $\begin{array}{l}11 \\
(10-11)\end{array}$ & $\begin{array}{l}7 \\
(7-8)\end{array}$ & $\begin{array}{l}3 \\
(3-4)\end{array}$ & $\begin{array}{l}4 \\
(3-5)\end{array}$ & $\begin{array}{l}3 \\
(2-4)\end{array}$ & $\begin{array}{l}3.1 \\
(2.0-4.1)\end{array}$ \\
\hline $25-40 \mathrm{~cm}$ & $\begin{array}{l}66 \\
(63-71)\end{array}$ & $\begin{array}{l}15 \\
(14-17)\end{array}$ & $\begin{array}{l}8 \\
(7-9)\end{array}$ & $\begin{array}{l}6 \\
(6-7)\end{array}$ & $\begin{array}{l}2 \\
(1-3)\end{array}$ & $\begin{array}{l}2 \\
(1-2)\end{array}$ & $\begin{array}{l}1 \\
(<1-2)\end{array}$ & $\begin{array}{l}1.0 \\
(0.5-1.6)\end{array}$ \\
\hline
\end{tabular}

Agronomic P status of the Ap horizon was classified as "good" for Field 1 (under shallow autumn cultivation) and "satisfactory" for Field 2 (ploughed). Soil test $P$ concentration $\left(P_{A C}\right)$ was determined by extraction with acidic ammonium acetate ( $\mathrm{pH} 4.65$, Vuorinen and Mäkitie 1955). The $\mathrm{P}_{\mathrm{Ac}}$ concentrations and $\mathrm{pH}$ for plots subjected to randomized treatments are shown in Table 2, as measured at the beginning of the study and during the final monolith sampling in the spring of 2011. 
Table 2. Soil test $\mathrm{P}$ (PAc, ammonium acetate, $\mathrm{pH}$ 4.65) concentrations and $\mathrm{pH}$ as measured in the Ap horizon of the plots subjected to different treatments. Soil test $\mathrm{P}$ and $\mathrm{pH}$ are given as mean values, with standard errors in parentheses $(n=4)$. Samples collected in 2008 represent soil conditions before the amendment applications and samples collected in 2011 represent soil conditions at the time of final soil monolith sampling (31 months after the amendments were applied).

\begin{tabular}{|c|c|c|c|c|}
\hline & $\begin{array}{l}\text { Unamended } \\
\text { control }\end{array}$ & $\begin{array}{l}\text { Limestone }\left(\mathrm{CaCO}_{3}\right) \\
4.3 \mathrm{Mg} \mathrm{ha}^{-1}\end{array}$ & $\begin{array}{l}\text { Gypsum } \\
3 \mathrm{Mg} \mathrm{ha}^{-1}\end{array}$ & $\begin{array}{l}\text { Gypsum } \\
6 \mathrm{Mg} \mathrm{ha}^{-1}\end{array}$ \\
\hline \multicolumn{5}{|c|}{ Field 1 (cultivation to $10 \mathrm{~cm}$ depth) } \\
\hline \multicolumn{5}{|l|}{ Aug 2008} \\
\hline $\mathrm{P}_{\mathrm{Ac}^{\prime}} \mathrm{mg} \mathrm{l}^{-1}$ & $13.6(1.0)$ & $12.6(1.4)$ & $15.1(1.7)$ & $14.0(1.7)$ \\
\hline $\mathrm{pH}$ & $6.2(0.05)$ & $6.3(0.06)$ & $6.3(0.08)$ & $6.3(0.07)$ \\
\hline \multicolumn{5}{|l|}{ May 2011} \\
\hline $\mathrm{P}_{\mathrm{Ac}^{\prime}} \mathrm{mg} \mathrm{l}^{-1}$ & $13.9(1.9)$ & $14.7(2.5)$ & $14.6(2.8)$ & $16.1(2.9)$ \\
\hline $\mathrm{pH}$ & $6.3(0.05)$ & $6.5(0.004)$ & $6.1(0.04)$ & $6.2(0.08)$ \\
\hline \multicolumn{5}{|c|}{ Field 2 (ploughed to $20 \mathrm{~cm}$ depth) } \\
\hline \multicolumn{5}{|l|}{ Aug 2008} \\
\hline $\mathrm{P}_{\mathrm{AC}^{\prime}} \mathrm{mg} \mathrm{l}^{-1}$ & $8.4(0.7)$ & $9.0(0.6)$ & - & $8.3(0.5)$ \\
\hline $\mathrm{pH}$ & $6.0(0.02)$ & $6.0(0.02)$ & & $5.9(0.06)$ \\
\hline \multicolumn{5}{|l|}{ May 2011} \\
\hline $\mathrm{P}_{\mathrm{Ac}^{\prime}} \mathrm{mg} \mathrm{l}^{-1}$ & $9.0(1.1)$ & $10.2(0.5)$ & - & $8.8(0.5)$ \\
\hline $\mathrm{pH}$ & $6.2(0.09)$ & $6.2(0.03)$ & & $6.0(0.04)$ \\
\hline
\end{tabular}

Gypsum used in this study was obtained from the Yara Suomi Oy plant in Siilinjärvi, eastern central Finland. This gypsum is a side-product of apatite refining/phosphoric acid process and thus contains a small proportion of residual P. The Siilinjärvi ore has a relatively low apatite content of about $10 \%$, and low concentrations of radionuclides (Karhunen and Vermeulen 2000) and other heavy and/or harmful elements. The concentrations of selected elements as measured in the gypsum used in this study are given below (Aqua Regia-extractable elements):

\author{
$\left(\mathrm{g} \mathrm{kg}^{-1}\right) \quad$ Ca 218, S 180, P 1.6, Fe 0.83, and Na 0.1 \\ $\left(\mathrm{mg} \mathrm{kg}^{-1}\right) \quad \mathrm{K} 80, \mathrm{Cu} 12, \mathrm{Mg} \mathrm{10}, \mathrm{Zn} \mathrm{1.4,} \mathrm{Mn} \mathrm{0.5,} \mathrm{Pb} \mathrm{3.2,} \mathrm{and} \mathrm{Cd} 0.02$
}

Agricultural lime (ground $\mathrm{CaCO}_{3}$ rock) was used in this study as an alternative Ca-rich amendment for comparison with gypsum. The origin of this lime was meta-limestones of the Limberg/Skräbböle quarry (Nordkalk Oy Ab, Pargas, SW Finland). Both limestone and gypsum amendments were broadcast in the study plots in October of 2008. Plots were then turned within one week of the application with either a cultivator to a depth of about 10 $\mathrm{cm}$ (Field 1), or by ploughing to an approximate depth of $20 \mathrm{~cm}$ (Field 2). Tillage procedures were repeated following the autumn harvests in 2009 and 2010.

The soil amendment applications were randomized by splitting the $100 \times 20 \mathrm{~m}$ field areas into 4 blocks with one replicate of each treatment randomly applied to each block (thus, four replicate plots at both field sites). Field 1 (cultivation to $10 \mathrm{~cm}$ depth) was subjected to four treatments: (i) no amendments (Ctrl), (ii) limestone applied at $4.3 \mathrm{Mg} \mathrm{ha}^{-1}$ (Lime), (iii) gypsum applied at $3 \mathrm{Mg} \mathrm{ha}^{-1}$ (Gyp 3), and (iv) gypsum applied at $6 \mathrm{Mg} \mathrm{ha}^{-1}$ (Gyp 6). The Gyp 6 application (22\% Ca-content in gypsum) supplied the same total Ca as the limestone application (30\% Cacontent) at $4.3 \mathrm{Mg} \mathrm{ha}^{-1}$. Field 2 (ploughed to $20 \mathrm{~cm}$ ) was subjected to treatments i, ii and iv above, but not to the Gyp 3 application (treatment iii).

Fields 1 and 2 were cultivated for spring-sown wheat (Triticum aestivum L. 'Kruunu') during the growing seasons spanned by this study, i.e., crop years 2009 and 2010. The fields were fertilized with mineral fertilizer (saltpetre, NPKS 27-0-1-4) with a $\mathrm{N}$ application rate of $100 \mathrm{~kg} \mathrm{ha}^{-1}$. The fertilizer did not include a P application because soil tests indicated a sufficiently high P concentration. The gypsum amendments however supplied around $5 \mathrm{~kg} P$ (as residual P) at the lower application level (Gyp 3) and about $10 \mathrm{~kg} P$ at the higher rate (Gyp 6) in the autumn of 2008 when the amendments were applied. 


\section{Rainfall simulations}

An undisturbed soil monolith measuring $30 \mathrm{~cm}$ in diameter and about $40 \mathrm{~cm}$ in depth was annually collected from each of the field plots during the month of May starting in 2009 (each spring 16 monoliths from Field 1 and 12 from Field 2, 4 replicates per treatment). The monoliths were collected using a tractor-driven soil auger similar to that described in Persson and Bergström (1991) and PVC cylinders (0.5 m in length) (see online supplementary material, Photographs 1 and 2). The monoliths were capped with soft foam caps, transported to the laboratory and stored in darkness at $+6^{\circ} \mathrm{C}$.

Having formed in the post-glacial period with pronounced seasonal variations in water flow and sediment deposition, the soils under investigation have horizontal planes of weakness along slightly variably-grained horizons deposited during spring and autumn. The basal section of most monoliths broke along these stable ped boundaries during sampling. The blade and cutter tip of the coring device however disturbed some sections of the monoliths during sampling. These disturbed basal sections therefore required manual preparation so as to include natural cleavage planes of the soil instead of disturbed soil.

The monoliths were prepared as follows. First, the top of the monolith was stabilized with soft foam, and the soil core was then carefully inverted so that the disturbed parts of the core base could be manually prepared (see online supplementary material, Photograph 3). After preparation, the base was vacuumed, empty spaces filled with washed quartz gravel (about 4-6 $\mathrm{mm}$ diameter clasts), and then covered with nylon netting secured in place by an adjustable steel band affixed to the lower section of the core tube. The column was then returned to an upright position and attached to a $5 \mathrm{~cm}$ section of PVC pipe firmly glued to a basal plexiglass plate with a drainage hole and packed with quartz gravel. The overlying soil column was attached to the lower section using a $10 \mathrm{~cm}$ wide neoprene strip secured by adjustable steel bands to ensure that the core apparatus was properly sealed.

Each soil core was then slowly saturated from below (via the drainage hole) during one day and kept saturated over additional two days. After this saturation period, the drainage hole of the lower piece of the column apparatus was unstoppered and the soil column drained overnight. The volume of the drained water was measured and sampled. Water samples were frozen and stored at $-18^{\circ} \mathrm{C}$ for later analysis.

Rainfall was simulated using a stationary drop-former type rain maker as described in Uusitalo and Aura (2005). This device pumps deionized water through a column maintained at a constant water level into $0.51 \mathrm{~mm}$ diameter capillary tubes. The capillary tubes (96 in total) attach to a $1 \times 1 \mathrm{~m}$ steel frame to produce droplets weighing around $37.5 \mathrm{mg}$ at a desired interval (see online supplementary material, Photographs 4 through 6 ). The fall height in our simulations was set at $2.4 \mathrm{~m}$. Based on drop size and fall height, we estimated the kinetic energy of the simulated rain to be about $80 \mathrm{~J} \mathrm{~m}^{-2} \mathrm{~h}^{-1}$. The fall height was not sufficient for the drops to reach terminal velocity but yielded kinetic energy similar to that observed in natural rainfall of the same $\left(5 \mathrm{~mm} \mathrm{~h}^{-1}\right)$ intensity (cf. Salles et al. 2002); the larger droplet size of the simulated raindrops compensates for their lower impact velocity relative to natural raindrops. Simulated rainfall was applied for 5 hours per day over two consecutive days at an intensity of $5 \mathrm{~mm} \mathrm{~h}^{-1}$ ( $25 \mathrm{~mm}$ of rain per day and $50 \mathrm{~mm}$ total). A $5 \mathrm{~mm} \mathrm{~h}^{-1}$ rainfall intensity is typical of conditions in SW Finland (see Kuusisto 1980). Climatological and meteorological data from the Jokioinen observatory show that daily precipitation exceeded $20 \mathrm{~mm}$ for an average of 2.4 days per year from 1991-2001 (see Turtola et al. 2007). Higher daily precipitation is less common: $50 \mathrm{~mm}$ of rain in one day for example would only occur once every 10 years (Venäläinen et al. 2009).

Four water samples from each soil core were collected during the rainfall simulations: (0) overnight drainage water (i.e., water that was collected from the initial saturation of the soil cores), (1) percolation water collected during the first day of simulated rain, (2) percolation water collected from overnight drainage following the first day of simulated rain, and (3) percolation water collected during the second day of simulated rain. The numbers in parentheses above designate each water sample along the $x$-axes of Figures 1 through 3 . The water samples were subdivided into two fractions. The first fraction was immediately filtered through $0.2 \mu \mathrm{m}$ Nuclepore (Whatman, Maidstone, UK) membranes. Both filtered and unfiltered subsamples were stored at $-18^{\circ} \mathrm{C}$ for later analysis.

The filtered subsamples were analysed for $\mathrm{DRP}, \mathrm{NO}_{3}-\mathrm{N}, \mathrm{NH}_{4}-\mathrm{N}, \mathrm{Ca}^{2+}, \mathrm{K}^{+}, \mathrm{Mg}^{2+}$, and $\mathrm{S}$. Sulphur concentrations and knowledge of the initial filtering technique used suggest that $\mathrm{S}$ consisted mostly of $\mathrm{SO}_{4}-\mathrm{S}$, with a minor contribution from organosulphur species within the dissolved organic matter fraction. The unfiltered subsamples were analysed for total $\mathrm{P}$ and $\mathrm{N}$ concentrations following autoclave induced digestion with peroxodisulphate and sulphuric acid. The differences between the concentrations of total and dissolved forms were taken to represent particu- 
late $\mathrm{P}(\mathrm{PP})$ and organic $\mathrm{N}\left(\mathrm{N}_{\text {org }}\right)$. Phosphorus and nitrogen species were analysed with a LaChat analyser (Milwaukee, WI, USA) while $\mathrm{Ca}^{2+}, \mathrm{Mg}^{2+}, \mathrm{K}^{+}$and $\mathrm{S}$ were measured using an ICP-AES (Thermo Jarrel Ash, Franklin, MA, USA).

For dissolved organic carbon (DOC) analyses, samples were passed through Whatman GF/C glass filters (instead of Nuclepore membranes) and then analysed with a Shimadzu TOC analyser (Tokyo, Japan). Turbidity of percolation water was recorded immediately following collection using a Hach 2100 AN IS Turbidimeter (Loveland, CO, USA). This instrument measures nephelometric turbidity units (NTU) over an undiluted range of up to $10^{4}$ NTU. For a set of about 50 water samples, total suspended solids (TSS) were additionally determined by weighing evaporation residue. Complementary turbidity and TSS data allowed us to calculate TSS as a function of turbidity measurements (NTU):

$$
\text { TSS }\left(\mathrm{g}^{-1}\right)=-4.414 \times \exp (-0.0001617 \times \mathrm{NTU})+4.558\left(\mathrm{r}^{2}=0.96\right)
$$

Electrical conductivity (EC) was measured with an Orion 150 conductivity meter (cell 012210), and pH was recorded with an Orion 420A meter ( $\mathrm{pH}$ electrode 9457BN; Thermo Electron Corp., Waltham, MA, USA).

\section{Statistical analyses}

Statistical analyses were performed using the SAS software package (SAS Institute, Inc., Cary, NC, USA). Variables with normally distributed residuals such as $\mathrm{pH}$, or those that could be normalized by logarithmic (DRP, DOC) or square root (PP, TP, N forms, K) transformations were analysed using the SAS 'MIXED' procedure which executes a Restricted Estimation of Maximum Likelihood (REML) method. Variables for year, treatment and a within-simulation samples variable (abbreviated below as "WSS") were denoted as fixed effects. The WSS variable, compounding individual water samples $(0,1,2,3)$ taken at different times during the simulations, was fixed because it exhibited trends during the course of the simulation; the trends in concentrations are shown in Figures 1 through 3. The model takes into account that year and WSS were repeated measures having compound symmetry (CS) and unstructured (UN) covariance structure, respectively. The model can thus be expressed in equation form as follows:

$$
y_{i j k l}=\mu+B_{1+} T_{i}+T B_{i l}+Y_{j}+Y B_{j l}+T Y_{i j}+S_{k}+S B_{k l}+T S_{i k}+T S B_{i k l}+T Y S_{i j k}+T Y S B_{i j k l}+Y S_{j k}+Y S B_{j k l}+\varepsilon_{i j k}
$$

where $\mu$ is the overall mean, and $T_{i}, Y_{j}$ and $S_{k}$ are the fixed effects of the treatment, year and WSS, respectively. Two- and three-factor interactions of fixed effects were also included in the model. The terms $\mathrm{SB}_{\mathrm{kl}}, \mathrm{TB}_{\mathrm{il}}, \mathrm{YB}_{\mathrm{j} \mid}, \mathrm{TSB}_{\left.\mathrm{ik}\right|^{\prime}}$ $\mathrm{YSB}_{\mathrm{jkl}}$ and TYSB${ }_{\mathrm{ijkl}}$ represent random effects of interaction of the $B_{1}$ (block) term with other factors, and $\varepsilon_{\mathrm{ijk}}$ is the residual error. The Tukey-Kramer post-hoc test was used to compare means.

Certain variables (turbidity, $\mathrm{EC}, \mathrm{Ca}^{2+}, \mathrm{Mg}^{2+}, \mathrm{S}$ ) had demonstrably non-normal residual distributions and could not be normalized by log or square root transformations. These variables were analysed with the non-parametric Kruskall-Wallis test and by post-hoc comparison of contrasts between the treatments. Data from each field was analysed separately to account for the different depths of autumn tillage.

\section{Results}

\section{Turbidity of percolation water}

Turbidity levels and the treatment effects on turbidity were clearly variable over the three-year study period (Fig. 1, Table 3). The effect of the gypsum amendment on the turbidity of percolation water was especially dramatic for the first rainfall simulation (monolith sampling at 7 months after gypsum and limestone applications; online supplementary material, Photograph 7). Both levels of gypsum application (Gyp 3 and Gyp 6) were associated with dramatic decreases in turbidity, whereas the limestone application (Lime) had no apparent effect on turbidity. In the second year's simulation (at 19 months after amendment applications) turbidity was relatively high for water percolated through the monoliths (Fig. 1, Table 3); this effect was probably due to higher soil moisture levels during the second monolith sampling. At that time water samples from the gypsum-amended soil monoliths also exhibited only about $50 \%$ of the turbidity observed in those of the unamended control (Ctrl) or Lime soil. Turbidity generally increased with time as the second year's simulation proceeded (Fig. 1). By 31 months, water collected from initial saturation of gypsum amended soils (the 0 samples in Fig.1) had slightly lower turbidity than that from other treatments, but average values of the third year's simulations were statistically insignificant due to variation measured from replicate soil cores. 
Field 1, shallow cultivation
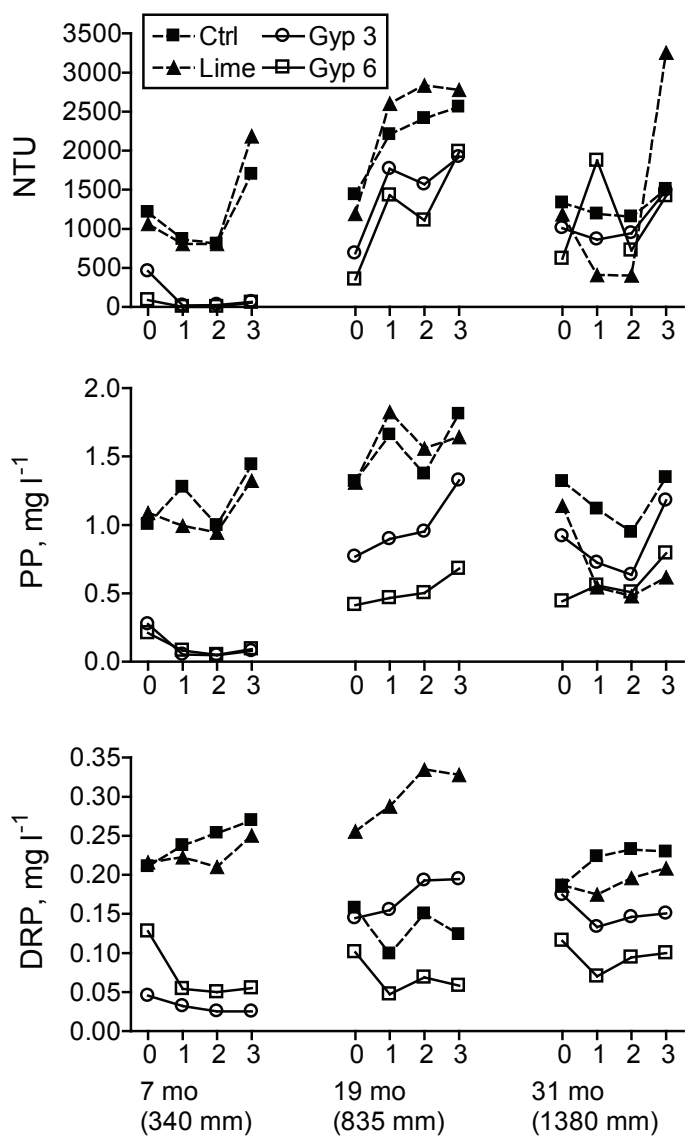

Field 2, ploughed
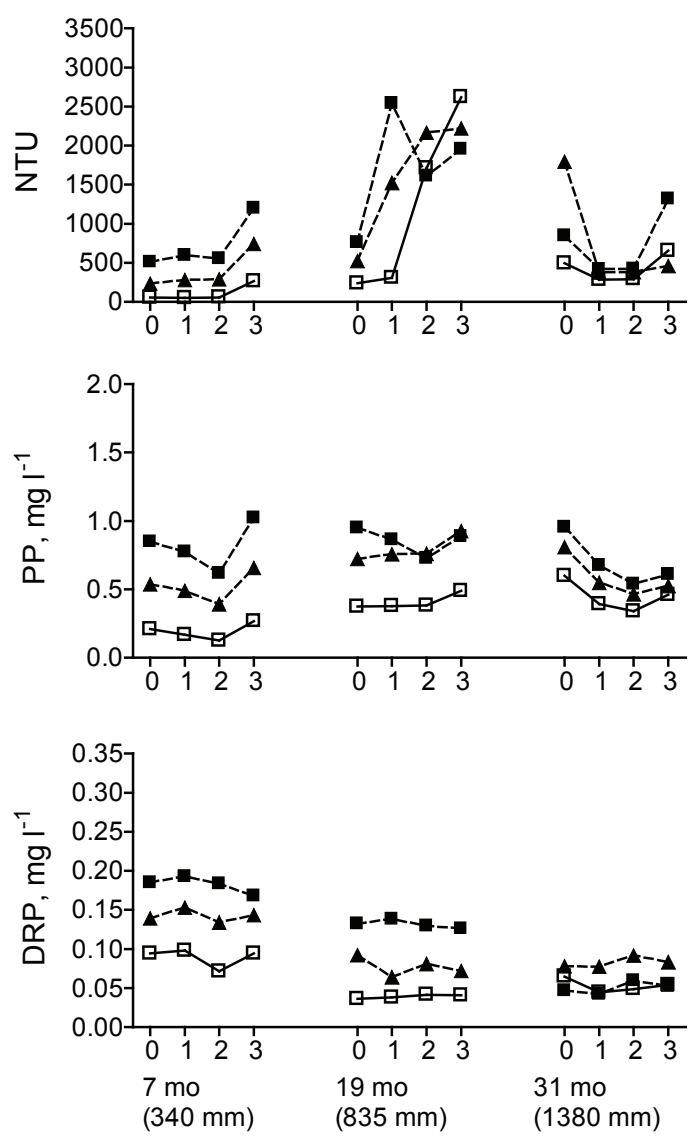

Fig. 1. Turbidity (NTU), particulate $P(P P)$ and dissolved reactive $P(D R P)$ concentrations in percolation water collected from soil monoliths (Fields 1 and 2) subjected to two-day rainfall simulations. Soil monoliths were collected 7, 19 and 31 months after limestone and gypsum applications. The markers show mean measurements for four replicate soil monoliths collected from plots of the unamended control soil (Ctrl), plots subjected to the limestone (Lime), the $3 \mathrm{Mg} \mathrm{ha}^{-1}$ gypsum (Gyp 3), and the $6 \mathrm{Mg}$ ha $^{-1}$ gypsum (Gyp 6) applications,. The subsets of $x$-axis markers indicate the four different water samples taken throughout the experiment: 0 - water draining overnight following the initial saturation of the soil cores; 1 - percolation water obtained during the first rainfall simulation event; 2 - water draining overnight following the first rainfall simulation event; and 3 - percolation water obtained during the second rainfall simulation event. On both days, simulations lasted for 5 hours with $5 \mathrm{~mm} \mathrm{~h}^{-1}$ rainfall intensity. The numbers in parentheses beneath the $x$-axis labels give the cumulative natural rainfall $(\mathrm{mm})$ in the field area following the initial amendment application.

Overall the results show that gypsum applications significantly reduced the turbidity of percolation water samples. The study-averaged turbidity of water samples from gypsum amended soil was $36-50 \%$ lower than that of water samples from the Ctrl and Lime soils (Table 3). For the two gypsum amendment levels applied to Field 1 , the Gyp 3 application resulted in a mean 43\% reduction, and Gyp 6 resulted in a mean 49\% reduction in turbidity. For Field 2 (Gyp 6) the respective turbidity reduction was $40 \%$. The unequal response of Field 1 and 2 to the Gyp 6 application is likely due to the different mixing depths of gypsum for ploughing versus cultivator tillage.

Estimates for treatment-averaged TSS (total suspended solids) concentrations were calculated using Eq. 1 and turbidity data (Table 3). Results of this procedure indicate that water samples from the Ctrl and Lime amended soils had TSS concentrations of about 0.8-1.2 $\mathrm{g} \mathrm{l}^{-1}$. Water samples from the gypsum amended soils gave estimated TSS concentrations of $0.5-0.7 \mathrm{~g} \mathrm{l}^{-1}$. The lowest turbidity measurement belonged to a water sample from the first sampling (7 months) of a gypsum amended soil and corresponded to a TSS concentration of about $0.2 \mathrm{~g} \mathrm{l}^{-1}$. 
Table 3. Turbidity, and concentrations of particulate $P(P P)$ and dissolved reactive $P(D R P)$ in percolation water samples obtained from $40-\mathrm{cm}$ deep undisturbed soil monoliths subjected to rainfall simulations. The monoliths were sampled from Fields 1 and 2 over three consecutive spring periods (7, 9 and 31 months) following an initial limestone and gypsum application. The numbers given in the table represent averages from four different water samples collected during two-day rainfall simulations. The mean concentrations of water samples collected from soils subjected to each treatment and averaged over the entire study are shown at the bottom. The superscript tags indicate significant $(p<0.05)$ differences between the treatments; mean values that do not differ statistically significantly are marked with the same letters. The different treatments include the unamended control soil (Ctrl), limestone amended soil (Lime), the $3 \mathrm{Mg} \mathrm{ha}^{-1}$ gypsum application (Gyp 3), and the $6 \mathrm{Mg}$ ha-1 gypsum application (Gyp 6). N.A. = not applicable (the $3 \mathrm{Mg} \mathrm{ha}^{-1}$ gypsum amendment was not applied to Field 2 plots).

\begin{tabular}{|c|c|c|c|c|c|c|}
\hline & \multicolumn{3}{|c|}{ Field 1 (cultivation to $10 \mathrm{~cm}$ depth) } & \multicolumn{3}{|c|}{ Field 2 (ploughed to $20 \mathrm{~cm}$ depth) } \\
\hline & Turbidity & PP & DRP & \multirow{2}{*}{$\begin{array}{l}\text { Turbidity } \\
\text { NTU }\end{array}$} & \multirow[t]{2}{*}{$\mathrm{PP}$} & \multirow[t]{2}{*}{ DRP } \\
\hline & NTU & $\longrightarrow$ & - & & & \\
\hline & \multicolumn{6}{|c|}{7 months after amendment applications $(n=16)$} \\
\hline Ctrl & $1148^{a}$ & $1.157^{\mathrm{a}}$ & $0.223^{\mathrm{a}}$ & $716^{\mathrm{a}}$ & $0.792^{\mathrm{a}}$ & 0.126 \\
\hline Lime & $1217^{a}$ & $1.034^{\mathrm{a}}$ & $0.189^{\mathrm{a}}$ & $388^{\mathrm{a}, \mathrm{b}}$ & $0.502^{\mathrm{a}, \mathrm{b}}$ & 0.137 \\
\hline Gyp 3 & $145^{\mathrm{b}}$ & $0.093^{b}$ & $0.021^{\mathrm{b}}$ & N.A. & N.A. & N.A. \\
\hline \multirow[t]{2}{*}{ Gyp 6} & $39^{b}$ & $0.098^{\mathrm{b}}$ & $0.054^{\mathrm{b}}$ & $109^{\mathrm{b}}$ & $0.182^{\mathrm{b}}$ & 0.074 \\
\hline & \multicolumn{6}{|c|}{19 months after amendment applications $(n=16)$} \\
\hline Ctrl & $2153^{\mathrm{a}}$ & $1.521^{\mathrm{a}, \mathrm{b}}$ & $0.117^{\mathrm{a}}$ & $1717^{\mathrm{a}}$ & 0.846 & 0.119 \\
\hline Lime & $2352^{a}$ & $1.540^{\mathrm{a}}$ & $0.209^{\mathrm{a}, \mathrm{b}}$ & $1609^{a}$ & 0.781 & 0.073 \\
\hline Gyp 3 & $1486^{\mathrm{a}, \mathrm{b}}$ & $0.933^{\mathrm{a}, \mathrm{b}}$ & $0.120^{\mathrm{a}, \mathrm{b}}$ & N.A. & N.A. & N.A. \\
\hline \multirow[t]{2}{*}{ Gyp 6} & $1220^{\mathrm{b}}$ & $0.480^{\mathrm{b}}$ & $0.051^{b}$ & $1221^{b}$ & 0.390 & 0.034 \\
\hline & \multicolumn{6}{|c|}{31 months after amendment applications $(n=16)$} \\
\hline Ctrl & 1296 & 1.110 & 0.154 & 752 & 0.660 & 0.037 \\
\hline Lime & 1315 & 0.657 & 0.159 & 754 & 0.579 & 0.080 \\
\hline Gyp 3 & 1079 & 0.838 & 0.131 & N.A. & N.A. & N.A. \\
\hline \multirow[t]{2}{*}{ Gyp 6} & 1159 & 0.523 & 0.073 & 433 & 0.399 & 0.043 \\
\hline & \multicolumn{6}{|c|}{ Mean values averaged over the entire study $(n=48)$} \\
\hline Ctrl & $1532^{\mathrm{a}}$ & $1.256^{\mathrm{a}}$ & $0.159^{\mathrm{a}}$ & $1052^{\mathrm{a}}$ & $0.764^{\mathrm{a}}$ & $0.084^{\mathrm{a}}$ \\
\hline Lime & $1628^{a}$ & $1.046^{\mathrm{a}}$ & $0.185^{\mathrm{a}}$ & $917^{a}$ & $0.615^{\mathrm{a}}$ & $0.093^{\mathrm{a}}$ \\
\hline Gyp 3 & $903^{b}$ & $0.531^{\mathrm{b}}$ & $0.073^{b}$ & N.A. & N.A. & N.A. \\
\hline Gyp 6 & $806^{\mathrm{b}}$ & $0.332^{\mathrm{b}}$ & $0.059^{b}$ & $588^{b}$ & $0.314^{\mathrm{b}}$ & $0.048^{b}$ \\
\hline
\end{tabular}

\section{Phosphorus concentrations in percolation water}

In a manner similar to that of turbidity, trends in P concentrations in water samples from soils collected throughout the study differed over time. Water samples of the first year simulations ( 7 months) were highly different in their PP concentrations, with the lowest values in gypsum amended soils (Fig. 1, Table 3). At 19 months (second spring), water samples from Field 1 plots subjected to the Gyp 6 application still exhibited lower PP concentrations than those representing Ctrl and Lime treated soils. Water from Field 2 plots subjected to the Gyp 6 application however did not show statistically significant differences in PP concentrations relative to values associated with the other treatments (Table 3). By 31 months (third spring), the PP concentrations associated with the gypsum amendment were still on average about half of those of the Ctrl or Lime amended soils, but these differences were not statistically significant given the standard errors of the mean values.

Taken over the whole duration of the study, PP concentrations in water collected from the gypsum amended soils were $49-74 \%$ lower than those of Ctrl and Lime soils (Table 3). The gypsum applications to Field 1 were followed by PP concentrations that were 53\% (Gyp 3) and 71\% (Gyp 6) lower on average (respectively) than values associated with other treatments. For Field 2, PP concentrations from Gyp 6 were 54\% lower than for the Ctrl.

The response of the treatments in DRP concentrations also varied through time of monolith sampling. When the entire study period was concerned gypsum amended soils had statistically lower DRP concentrations in percola- 
tion water than those of the Ctrl and Lime. The post-hoc test however only identified significant treatment effects within a given sampling among Field 1 percolation water samples at 7 and 19 months samplings. On the contrary, the statistical test failed to identify any significant yearly differences between the treatments for Field 2 (Table 3).

When averaged over the 31-month duration of the study, water samples from gypsum amended soils had DRP concentrations that were 43-68\% below those associated with Ctrl and Lime amended soils (Table 3). Water samples from Lime soils had slightly (10-14\%) higher average DRP concentrations relative to those of the Ctrl. Water samples from Field 1 soils subjected to the Gyp 3 and Gyp 6 applications had DRP concentrations that were 57\% and $66 \%$ lower, respectively, than that of water from the Ctrl. For Field 2 the respective reduction in the DRP concentrations for Gyp 6 was $46 \%$.

\section{Mobility of DOC and N species}

The concentrations of DOC in water samples from gypsum amended soils were consistently lower than those of the Ctrl and Lime soils for each year of the study (Fig. 2). These differences were statistically significant at 7 and 19 months but became non-significant at 31 months. Water samples from the Lime soil yielded the highest DOC concentrations among the treatments (Table 4). When averaged over the duration of the study, DOC values in water samples from gypsum amended soils were $32-45 \%$ lower than those associated with the Ctrl and Lime soils.

Field 1, shallow cultivation
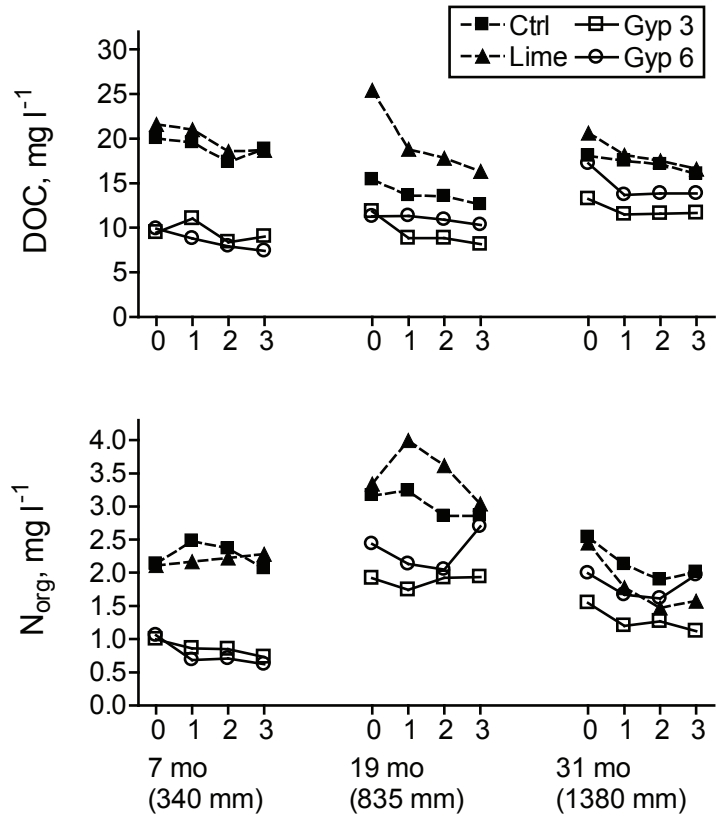

Field 2, ploughed
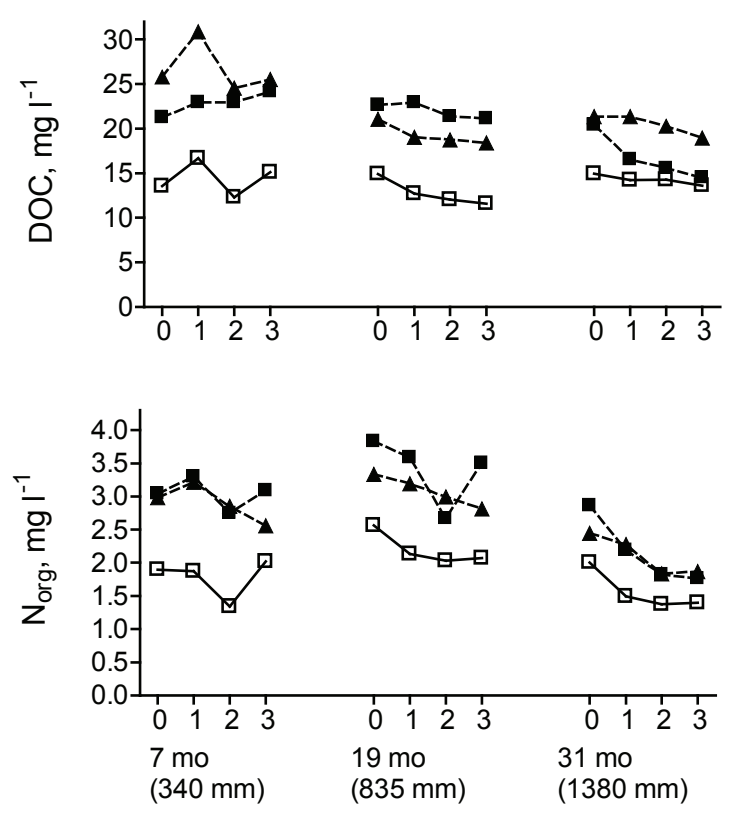

Fig. 2. The concentrations of dissolved organic $C(D O C)$ and of organic $N$ in percolation water samples collected from soil monoliths (Fields 1 and 2) subjected to two-day rainfall simulations. For the other labels, see the caption of Fig. 1.

The concentrations of organic $\mathrm{N}\left(\mathrm{N}_{\text {org }}\right.$, calculated as the difference between total $\mathrm{N}$ and the sum of $\mathrm{NO}_{3}-\mathrm{N}$ and $\mathrm{NH}_{4}-\mathrm{N}$ ) in water samples from gypsum amended soils were lower than those measured in water samples from the Ctrl and Lime soils (Table 4). Statistically lower concentrations of $\mathrm{N}_{\text {org }}$ were found for Field 1 for both Gyp 3 and Gyp 6 at 7 months and for Gyp 6 at 19 months (Table 4). Water samples collected from Field 2 monoliths gave $\mathrm{N}_{\text {org }}$ concentrations that did not differ significantly from each other, given a $95 \%$ confidence interval. The post-hoc test comparison of $\mathrm{N}_{\text {org }}$ concentrations for the Gyp 6 amendment and that of Ctrl collected at 7 months however gave a $p$-value of 0.053 . When averaged over the entire study, $\mathrm{N}_{\text {org }}$ concentrations in water samples from gypsum amended soils were $35-47 \%$ lower than corresponding values associated with Ctrls. Both $\mathrm{N}_{\text {org }}$ and DOC concentrations followed trends similar to each other (Fig. 2).

The $\mathrm{NO}_{3}-\mathrm{N}$ and $\mathrm{NH}_{4}-\mathrm{N}$ concentrations in percolation water did not show statistically significant differences. Relative to other treatments the averaged concentrations of $\mathrm{NO}_{3}-\mathrm{N}$ were generally higher for gypsum amendment in Field 1, but lower in Field 2. The pattern in $\mathrm{NO}_{3}-\mathrm{N}$ concentrations for Field 1 versus Field 2 samples appeared in annual comparisons as well (Table 5). The $\mathrm{NH}_{4}-\mathrm{N}$ concentrations were low and showed no obvious trends. 
Table 4. The concentrations of dissolved organic C (DOC) and organic N (Norg) in percolation water obtained from soil monoliths subjected to rainfall simulations. For the other information, see the heading of Table 3.

\begin{tabular}{|c|c|c|c|c|}
\hline & \multicolumn{2}{|c|}{ Field 1 (shallow cultiv.) } & \multicolumn{2}{|c|}{ Field 2 (ploughed) } \\
\hline & DOC & Norg & DOC & Norg \\
\hline & \multicolumn{2}{|c|}{$\longrightarrow \mathrm{mg} \mathrm{l}^{-1} \longrightarrow$} & \multicolumn{2}{|c|}{$\longrightarrow \mathrm{mg} \mathrm{l}^{-1} \longrightarrow$} \\
\hline & \multicolumn{4}{|c|}{7 months after amendment applications ( $n=16)$} \\
\hline Ctrl & $18.7^{\mathrm{a}}$ & $2.25^{\mathrm{a}}$ & $22.5^{\mathrm{a}}$ & 2.99 \\
\hline Lime & $19.8^{\mathrm{a}}$ & $2.17^{a}$ & $26.4^{\mathrm{a}}$ & 2.87 \\
\hline Gyp 3 & $8.2^{\mathrm{b}}$ & $0.75^{b}$ & N.A. & N.A. \\
\hline \multirow[t]{2}{*}{ Gyp 6} & $9.4^{b}$ & $0.86^{b}$ & $14.18^{\mathrm{b}}$ & 1.74 \\
\hline & \multicolumn{4}{|c|}{19 months after amendment applications $(n=16)$} \\
\hline Ctrl & $13.7^{a, b}$ & $3.01^{a, b}$ & $21.82^{\mathrm{a}}$ & 3.31 \\
\hline Lime & $18.1^{\mathrm{a}}$ & $3.44^{\mathrm{a}}$ & $19.16^{\mathrm{a}, \mathrm{b}}$ & 3.06 \\
\hline Gyp 3 & $10.7^{b}$ & $2.28^{a, b}$ & N.A. & N.A. \\
\hline \multirow[t]{2}{*}{ Gyp 6} & $9.2^{\mathrm{b}}$ & $1.86^{\mathrm{b}}$ & $12.70^{\mathrm{b}}$ & 2.16 \\
\hline & \multicolumn{4}{|c|}{31 months after amendment applications $(n=16)$} \\
\hline Ctrl & 17.0 & 2.07 & 16.38 & 2.08 \\
\hline Lime & 17.8 & 1.78 & 20.40 & 2.09 \\
\hline Gyp 3 & 14.5 & 1.80 & N.A. & N.A. \\
\hline \multirow[t]{2}{*}{ Gyp 6} & 11.8 & 1.24 & 14.08 & 1.52 \\
\hline & \multicolumn{4}{|c|}{ Mean values averaged over entire study $(n=48)$} \\
\hline Ctrl & $16.3^{\mathrm{a}}$ & $2.43^{\mathrm{a}}$ & $20.1^{\mathrm{a}}$ & $2.77^{\mathrm{a}}$ \\
\hline Lime & $18.5^{a}$ & $2.42^{\mathrm{a}}$ & $21.9^{\mathrm{a}}$ & $2.66^{\mathrm{a}}$ \\
\hline Gyp 3 & $10.9^{b}$ & $1.53^{b}$ & N.A. & N.A. \\
\hline Gyp 6 & $10.1^{b}$ & $1.29^{b}$ & $13.6^{b}$ & $1.74^{b}$ \\
\hline
\end{tabular}

Table 5. The concentrations of dissolved $\mathrm{NO}_{3}-\mathrm{N}$ and $\mathrm{NH}_{4}-\mathrm{N}$ in percolation water obtained from soil monoliths subjected to rainfall simulations. For the other information, see the heading of Table 3.

\begin{tabular}{|c|c|c|c|c|}
\hline & \multicolumn{2}{|c|}{ Field 1 (shallow cultiv.) } & \multicolumn{2}{|c|}{ Field 2 (ploughed) } \\
\hline & $\mathrm{NO}_{3}-\mathrm{N}$ & $\mathrm{NH}_{4}-\mathrm{N}$ & $\mathrm{NO}_{3}-\mathrm{N}$ & $\mathrm{NH}_{4}-\mathrm{N}$ \\
\hline & \multicolumn{4}{|c|}{7 months after amendment applications ( $n=16)$} \\
\hline Ctrl & 1.386 & 0.029 & 6.581 & 0.057 \\
\hline Lime & 1.232 & 0.028 & 5.404 & 0.082 \\
\hline Gyp 3 & 2.576 & 0.043 & N.A. & N.A. \\
\hline Gyp 6 & 2.171 & 0.019 & 4.985 & 0.054 \\
\hline \multicolumn{5}{|c|}{19 months after amendment applications $(n=16)$} \\
\hline Ctrl & 1.545 & 0.026 & 2.331 & 0.058 \\
\hline Lime & 1.341 & 0.033 & 2.674 & 0.026 \\
\hline Gyp 3 & 1.185 & 0.038 & N.A. & N.A. \\
\hline Gyp 6 & 2.086 & 0.046 & 2.036 & 0.026 \\
\hline \multicolumn{5}{|c|}{31 months after amendment applications $(n=16)$} \\
\hline Ctrl & 1.687 & 0.065 & 3.098 & 0.037 \\
\hline Lime & 2.072 & 0.046 & 1.834 & 0.084 \\
\hline Gyp 3 & 1.908 & 0.052 & N.A. & N.A. \\
\hline Gyp 6 & 2.716 & 0.049 & 2.011 & 0.060 \\
\hline \multicolumn{5}{|c|}{ Mean averaged over the entire study; $n=48$ ) } \\
\hline Ctrl & 1.537 & 0.038 & 3.805 & 0.050 \\
\hline Lime & 1.527 & 0.035 & 3.138 & 0.058 \\
\hline Gyp 3 & 1.845 & 0.044 & N.A. & N.A. \\
\hline Gyp 6 & 2.316 & 0.036 & 2.865 & 0.044 \\
\hline
\end{tabular}




\section{Electrical conductivity, other nutrients, and pH}

At 7 months the EC values in percolation water were around 155-190 $\mu \mathrm{S} \mathrm{cm}^{-1}$ from the Ctrl and Lime treatments. In Field 1 they were twice as high $\left(350 \mu \mathrm{S} \mathrm{cm}^{-1}\right)$ for the Gyp 3, and four times as high $\left(745-820 \mu \mathrm{S} \mathrm{cm}^{-1}\right)$ for the Gyp 6 application (Fig. 3, Table 6). At 19 months EC decreased markedly relative to the previous spring, and continued to decrease moderately thereafter. Even at 31 months the EC values associated with the Gyp 6 application were greater than those of the Ctrl.

Trends observed in EC values were similar to those observed in $\mathrm{Ca}^{2+}$ and $\mathrm{S}$ concentration data (Fig. 3). Unlike $\mathrm{P}, \mathrm{N}$ and DOC concentrations, EC (along with $\mathrm{Ca}^{2+}$ and S) of the Gyp 6 application exhibited significant differences relative to the Ctrl throughout the 31-month study period (Table 6).

Field 1, shallow cultivation

Field 2, ploughed
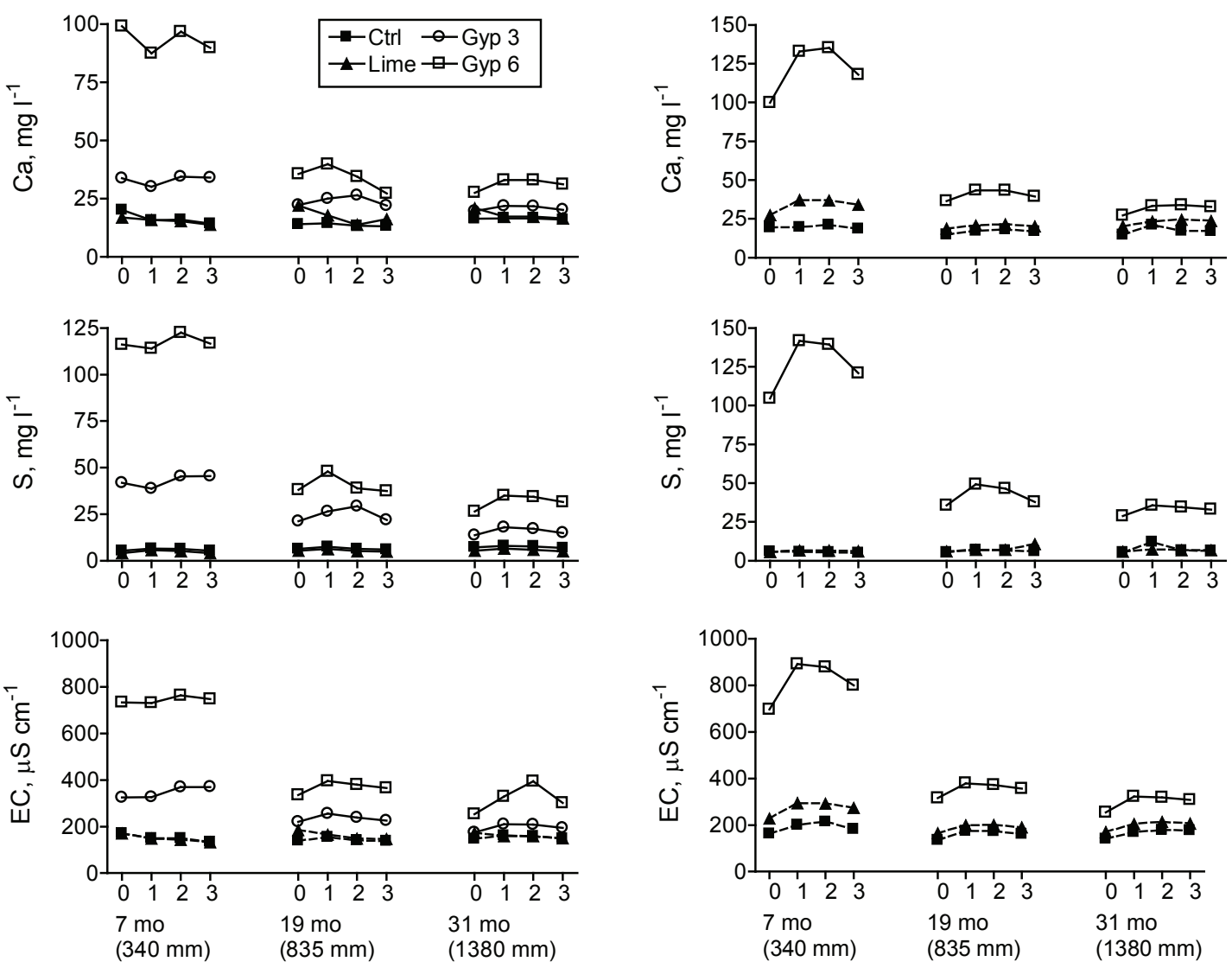

Fig. 3. The concentrations of dissolved $\mathrm{Ca}^{2+}$ and total dissolved $\mathrm{S}$, and electrical conductivity $(\mathrm{EC})$ of percolation water collected from soil monoliths (Fields 1 and 2) subjected to two-day rainfall simulations. For the other labels, see the caption of Fig. 1. 
Table 6. Electrical conductivity (EC) and the concentrations of dissolved $\mathrm{Ca}$ and $\mathrm{S}$ in percolation water obtained from soil monoliths subjected to rainfall simulations. For the other information, see the heading of Table 3.

\begin{tabular}{|c|c|c|c|c|c|c|}
\hline & \multicolumn{3}{|c|}{ Field 1 (cultivation to $10 \mathrm{~cm}$ depth) } & \multicolumn{3}{|c|}{ Field 2 (ploughed to $20 \mathrm{~cm}$ depth) } \\
\hline & \multirow{2}{*}{$\begin{array}{l}\text { EC } \\
\mu \mathrm{S} \mathrm{cm}^{-1}\end{array}$} & $\mathrm{Ca}^{2+}$ & S & \multirow{2}{*}{$\begin{array}{l}\mathrm{EC} \\
\mu \mathrm{S} \mathrm{cm}^{-1}\end{array}$} & \multirow[t]{2}{*}{$\mathrm{Ca}^{2+}$} & \multirow[t]{2}{*}{$\mathrm{S}$} \\
\hline & & $\longrightarrow$ & $\longrightarrow$ & & & \\
\hline & \multicolumn{6}{|c|}{7 months after amendment applications $(n=16)$} \\
\hline Ctrl & $151^{\mathrm{b}}$ & $16.5^{\mathrm{b}}$ & $5.9^{\mathrm{b}}$ & $190^{\mathrm{b}}$ & $20.0^{\mathrm{b}}$ & $5.5^{\mathrm{b}}$ \\
\hline Lime & $149^{b}$ & $15.5^{\mathrm{b}}$ & $4.7^{\mathrm{b}}$ & $273^{a}$ & $34.0^{\mathrm{a}}$ & $6.3^{\mathrm{b}}$ \\
\hline Gyp 3 & $348^{\mathrm{a}}$ & $33.1^{\mathrm{a}}$ & $42.9^{\mathrm{a}}$ & N.A. & N.A. & N.A. \\
\hline \multirow[t]{2}{*}{ Gyp 6} & $744^{\mathrm{a}}$ & $93.2^{\mathrm{a}}$ & $117.3^{\mathrm{a}}$ & $816^{a}$ & $121.5^{\mathrm{a}}$ & $126.7^{\mathrm{a}}$ \\
\hline & \multicolumn{6}{|c|}{19 months after amendment applications $(n=16)$} \\
\hline Ctrl & $143^{b}$ & $13.7^{c}$ & $6.5^{\mathrm{b}}$ & $161^{\mathrm{b}}$ & $16.8^{\mathrm{b}}$ & $6.3^{\mathrm{b}}$ \\
\hline Lime & $162^{\mathrm{b}}$ & $17.5^{b, c}$ & $5.4^{\mathrm{b}}$ & $189^{b}$ & $20.3^{b}$ & $7.8^{\mathrm{b}}$ \\
\hline Gyp 3 & $235^{a}$ & $23.9^{a, b}$ & $24.7^{\mathrm{a}}$ & N.A. & N.A. & N.A. \\
\hline \multirow[t]{2}{*}{ Gyp 6} & $369^{a}$ & $34.2^{\mathrm{a}}$ & $40.5^{\mathrm{a}}$ & $356^{\mathrm{a}}$ & $40.7^{\mathrm{a}}$ & $42.3^{\mathrm{a}}$ \\
\hline & \multicolumn{6}{|c|}{31 months after amendment applications $(n=16)$} \\
\hline Ctrl & $154^{b}$ & $16.3^{\mathrm{b}}$ & $7.5^{\mathrm{b}, \mathrm{c}}$ & $167^{b}$ & $17.5^{\mathrm{b}}$ & $7.7^{\mathrm{b}}$ \\
\hline Lime & $161^{b}$ & $18.0^{\mathrm{b}}$ & $5.8^{c}$ & $199^{a, b}$ & $23.0^{\mathrm{a}, \mathrm{b}}$ & $6.8^{\mathrm{b}}$ \\
\hline Gyp 3 & $197^{\mathrm{b}, \mathrm{a}}$ & $20.8^{a, b}$ & $16.0^{\mathrm{a}, \mathrm{b}}$ & N.A. & N.A. & N.A. \\
\hline \multirow[t]{2}{*}{ Gyp 6} & $320^{\mathrm{a}}$ & $31.1^{\mathrm{a}}$ & $31.9^{\mathrm{a}}$ & $301^{\mathrm{a}}$ & $31.9^{a}$ & $33.0^{\mathrm{a}}$ \\
\hline & \multicolumn{6}{|c|}{ Mean averaged over entire the study $(n=48)$} \\
\hline Ctrl & $149^{c}$ & $15.5^{c}$ & $6.6^{c}$ & $173^{c}$ & $18.0^{c}$ & $6.5^{\mathrm{b}}$ \\
\hline Lime & $157^{c}$ & $17.0^{c}$ & $5.3^{\mathrm{d}}$ & $220^{\mathrm{b}}$ & $25.8^{\mathrm{b}}$ & $6.9^{b}$ \\
\hline Gyp 3 & $260^{\mathrm{b}}$ & $25.9^{b}$ & $27.8^{\mathrm{b}}$ & N.A. & N.A. & N.A. \\
\hline Gyp 6 & $478^{a}$ & $52.9^{\mathrm{a}}$ & $63.2^{\mathrm{a}}$ & $491^{\mathrm{a}}$ & $64.7^{\mathrm{a}}$ & $67.4^{\mathrm{a}}$ \\
\hline
\end{tabular}

Averaged $\mathrm{Mg}^{2+}$ concentrations associated with the Ctrl ranged from 6.7-9.4 $\mathrm{mg} \mathrm{l}^{-1}$ while those of the Gyp 3 and Gyp 6 amended monoliths were twice and three times as high, respectively (Table 7). Comparison of annual variation in $\mathrm{Mg}^{2+}$ data shows that concentration peaked in the first year and then declined. $\mathrm{Mg}^{2+}$ concentrations remained significantly higher in water samples from the Gyp 6 application (relative to the values of the Ctrl) even after 31 months.

Concentrations of $\mathrm{K}^{+}$were apparently higher in water samples from the Gyp 6 applications but the overall treatment effect was statistically significant only for samples from Field 1 plots. The $\mathrm{K}^{+}$concentrations in water samples from soils receiving the Gyp 6 application were specifically 30-50\% higher than values associated with all other treatments, including the Gyp 3 application. Comparison of annual variation in $\mathrm{K}^{+}$data indicates that the only significant difference in concentrations exist between water samples from the Gyp 6 application and those of the Ctrl (Table 7). For Field 2, data on $\mathrm{K}^{+}$concentrations showed no significant annual differences among water samples representing the different soil treatments.

Soil pH (1:2.5 vol/vol soil-water suspension) as measured in the Ap horizon (6.0-6.5) showed relatively small variations between the treatments, or during the course of this study (Table 2). Percolation water from the soils analysed here ranged in $\mathrm{pH}$ from 7.0 to 8.0 (Table 8), thus clearly higher values than in soil suspensions. The lowest values, observed in water samples from the first year (7 months) soil monoliths subjected to the Gyp 6 application, were significantly lower than other $\mathrm{pH}$ values. The highest $\mathrm{pH}$ values were associated with Lime soils (Table 8). Water samples from gypsum amended soil collected during the second and third years had $\mathrm{pH}$ values similar to those of the Ctrl. 
Table 7. The concentrations of dissolved $\mathrm{Mg}^{2+}$ and $\mathrm{K}^{+}$in percolation water obtained from soil monoliths subjected to rainfall simulations. For the other information, see the heading of Table 3.

\begin{tabular}{|c|c|c|c|c|}
\hline & \multicolumn{2}{|c|}{ Field 1 (shallow cultiv.) } & \multicolumn{2}{|c|}{ Field 2 (ploughed) } \\
\hline & $\mathrm{Mg}^{2+}$ & $\mathrm{K}^{+}$ & $\mathrm{Mg}^{2+}$ & $\mathrm{K}^{+}$ \\
\hline & $\longrightarrow$ & & $\longrightarrow$ & - \\
\hline & \multicolumn{4}{|c|}{7 months after amendment applications $(n=16)$} \\
\hline Ctrl & $6.6^{b}$ & $3.50^{a, b}$ & $8.0^{c}$ & 3.41 \\
\hline Lime & $6.4^{\mathrm{b}}$ & $3.61^{a, b}$ & $10.7^{b}$ & 4.35 \\
\hline Gyp 3 & $18.8^{\mathrm{a}}$ & $2.25^{b}$ & N.A. & N.A. \\
\hline \multirow[t]{2}{*}{ Gyp 6} & $38.8^{\mathrm{a}}$ & $7.41^{\mathrm{a}}$ & $33.8^{\mathrm{a}}$ & 6.56 \\
\hline & \multicolumn{4}{|c|}{19 months after amendment applications $(n=16)$} \\
\hline Ctrl & $6.1^{\mathrm{b}}$ & 3.60 & $6.3^{b}$ & 2.23 \\
\hline Lime & $6.1^{b}$ & 5.18 & $8.2^{\mathrm{b}}$ & 1.76 \\
\hline Gyp 3 & $10.3^{\mathrm{a}}$ & 4.83 & N.A. & N.A. \\
\hline \multirow[t]{2}{*}{ Gyp 6} & $15.0^{\mathrm{a}}$ & 4.70 & $15.9^{\mathrm{a}}$ & 2.41 \\
\hline & \multicolumn{4}{|c|}{31 months after amendment applications $(n=16)$} \\
\hline Ctrl & $7.4^{\mathrm{b}}$ & 2.78 & $8.3^{b}$ & 1.41 \\
\hline Lime & $7.5^{b}$ & 2.71 & $9.4^{\mathrm{a}, \mathrm{b}}$ & 1.47 \\
\hline Gyp 3 & $8.9^{\mathrm{a}, \mathrm{b}}$ & 3.36 & N.A. & N.A. \\
\hline \multirow[t]{2}{*}{ Gyp 6} & $15.1^{\mathrm{a}}$ & 3.35 & $14.0^{\mathrm{a}}$ & 1.94 \\
\hline & \multicolumn{4}{|c|}{ Mean averaged over the entire study $(n=48)$} \\
\hline Ctrl & $6.7^{c}$ & $3.28^{b}$ & $7.5^{c}$ & 2.21 \\
\hline Lime & $6.7^{c}$ & $3.76^{a, b}$ & $9.4^{b}$ & 2.24 \\
\hline Gyp 3 & $12.7^{\mathrm{b}}$ & $3.40^{\mathrm{a}, \mathrm{b}}$ & N.A. & N.A. \\
\hline Gyp 6 & $23.0^{\mathrm{a}}$ & $5.02^{\mathrm{a}}$ & $12.1^{\mathrm{a}}$ & 3.12 \\
\hline
\end{tabular}

Table 8. Potential of hydrogen $(\mathrm{pH})$ in percolation water obtained from soil monoliths subjected to rainfall simulations. For the other information, see the heading of Table 3.

\begin{tabular}{|c|c|c|}
\hline & $\begin{array}{l}\text { Field } 1 \\
\mathrm{pH}\end{array}$ & $\begin{array}{l}\text { Field } 2 \\
\mathrm{pH}\end{array}$ \\
\hline & \multicolumn{2}{|c|}{7 months after application } \\
\hline Ctrl & $7.5^{\mathrm{a}, \mathrm{b}}$ & $7.4^{b}$ \\
\hline Lime & $7.6^{\mathrm{a}, \mathrm{b}}$ & $8.0^{\mathrm{a}}$ \\
\hline Gyp 3 & $7.7^{\mathrm{a}}$ & N.A. \\
\hline \multirow[t]{2}{*}{ Gyp 6} & $7.3^{\mathrm{b}}$ & $7.0^{\mathrm{b}}$ \\
\hline & \multicolumn{2}{|c|}{19 months after application } \\
\hline Ctrl & 7.7 & 7.8 \\
\hline Lime & 7.9 & 8.0 \\
\hline Gyp 3 & 7.6 & N.A. \\
\hline \multirow[t]{2}{*}{ Gyp 6} & 7.7 & 7.7 \\
\hline & \multicolumn{2}{|c|}{31 months after application } \\
\hline Ctrl & 7.7 & 7.7 \\
\hline Lime & 7.8 & 7.9 \\
\hline Gyp 3 & 7.5 & N.A. \\
\hline \multirow[t]{2}{*}{ Gyp 6} & 7.6 & 7.5 \\
\hline & \multicolumn{2}{|c|}{ Mean values for entire study } \\
\hline Ctrl & $7.6^{\mathrm{a}, \mathrm{b}}$ & $7.6^{\mathrm{b}}$ \\
\hline Lime & $7.8^{\mathrm{a}}$ & $8.0^{\mathrm{a}}$ \\
\hline Gyp 3 & $7.6^{\mathrm{a}, \mathrm{b}}$ & N.A. \\
\hline Gyp 6 & $7.5^{\mathrm{b}}$ & $7.4^{\mathrm{c}}$ \\
\hline
\end{tabular}




\section{Discussion}

The estimated TSS concentrations were checked against data from a 10-year field study conducted in a nearby area of Jokioinen/Kotkanoja that employed field-size lysimeters (0.5-ha hydrologically isolated plots equipped with runoff and drainflow collectors). The average estimated TSS concentrations reported here for the unamended controls are similar to the peak TSS concentrations measured for surface runoff and subsurface drainage waters by Turtola et al. (2007). Respectively, the lowest estimated TSS concentrations in the present study were observed during the first year sampling period and are similar to those measured during baseflow conditions for the Jokioinen/Kotkanoja field (Turtola et al. 2007). Also the PP concentrations observed by this work are similar to phosphorus data from the Jokioinen/Kotkanoja field reported in Uusitalo et al. (2007). The rainfall simulations described here therefore probably produced percolation water with somewhat higher TSS and PP than are typically measured in drainflow water samples, but were generally plausible given findings from the mentioned field studies conducted in the area. Higher TSS and PP concentrations observed here may relate to the relatively high daily rainfall applied during the simulations. Data from the Jokioinen Observatory (see Turtola et al. 2007) however indicates that the rainfall events that we simulated (rainfall exceeding $20 \mathrm{~mm}$ ) have on average occurred on 2.4 days per year during the period from 1991-2001.

The DRP concentrations in percolation water from the unamended controls were higher for Field 1 than for Field 2. We interpret this as a result of differences in soil test $P$ concentrations $\left(P_{A c} 13-15\right.$ for Field 1 vs. 8-9 mg ${ }^{-1}$ for Field 2). The relationship between soil test $P\left(P_{A C}\right)$ and average DRP indicated that a unit of $P_{A C}$ concentration in the soil corresponded to about $10 \mu \mathrm{g} \mathrm{I}^{-1} \mathrm{DRP}$ in percolation water. This finding is consistent with results of earlier rainfall simulations by Uusitalo and Aura (2005), conducted on 13 clay soils with $\mathrm{P}_{\mathrm{Ac}}$ concentrations up to $25 \mathrm{mg}$ $\mathrm{I}^{-1}$. In that study a unit increase in $\mathrm{P}_{\mathrm{AC}}$ was accompanied by a $9 \mu \mathrm{g} \mathrm{I}^{-1}$ increase in DRP. Runoff and drainflow from ploughed plots in the Jokioinen/Kotkanoja area yielded water samples with a similar mean DRP concentration vs. soil test $P$ relationship (Uusitalo et al. 2007). We therefore interpret the DRP concentrations reported here as reasonably accurate estimates for water draining from fields that have the observed levels of soil test $P$ concentrations.

For soils subjected to gypsum amendments, turbidity and the concentrations of DRP and PP decreased over the three-year study period by about 50-70\%. A likewise substantial decrease in P transfer is reported in a catchmentscale study by Ekholm et al. (2012). The study by Ekholm et al. (2012) monitored a 245 ha clay loam-dominated catchment with about $40 \%$ field coverage, wherein a majority of the fields received a $4.1 \mathrm{Mg} \mathrm{ha}^{-1}$ gypsum amendment in the autumn of 2008. In their comparison of water quality in the catchment outlet to that of water draining from a nearby reference catchment, Ekholm et al. (2012) estimate that the gypsum amendment reduced PP losses by $64 \%$ and DRP losses by about $33 \%$.

Earlier field and catchment-scale studies did not find a particularly strong concordant relationship between gypsum and P retention. Cox et al. (2005) for example conducted a paired catchment study which evaluated gypsum's efficacy in decreasing P runoff from contrast-textured soils of the Adelaide hills, South Australia. This study used a gypsum amendment of $15 \mathrm{Mg} \mathrm{ha}^{-1}$ and found that it modified the water flow pathways. Cox et al. (2005) specifically attributed reduced surface runoff observed for gypsum amended soils to enhanced percolation and increased aggregation and aggregate stability in the deeper parts of the soil profile. A marked shift from overland flow to interflow along the textural gradients in the soil profile was not however directly translated to a corresponding decrease in $\mathrm{P}$ concentration of water draining from the gypsum amended area. The average reductions in total $\mathrm{P}$ in overland flow and interflow were $35 \%$ and $11 \%$, respectively (Cox et al. 2005).

Many empirical studies of gypsum effects on P solubility use relatively short-term soil incubations and small column experiments (e.g., Zhu and Alva 1994, Anderson et al. 1995, O'Connor et al. 2005) and rarely include estimates of the duration of the observed effects. A particularly short-duration effect was reported by Watts and Torbert (2009) who observed about $20 \%$ reduction in DRP concentration as a result of gypsum amendment during an initial 30 minute concentrated flow event applied immediately following a poultry litter application and gypsum amendment to a set of test plots. These workers conducted a second 30 minute runoff event four weeks later and found that DRP concentration was highest $\left(4.3 \mathrm{mg} \mathrm{l}^{-1}\right)$ in runoff from the plot that had received the highest amount of gypsum dressing. Other plots supplied runoff with DRP concentrations similar to those of the unamended control (3.1-3.3 $\left.\mathrm{mg} \mathrm{l}^{-1}\right)$. The gypsum amendment did not apparently reduce DRP in concentrated runoff after one month from the application (Watts and Torbert, 2009).

In our study the effects of gypsum amendments were most evident in samples collected in the first 7 months after the initial application, and then gradually declined until the end of the study. By the third year sampling period 
the gypsum amended soils had been subjected to about $1400 \mathrm{~mm}$ of cumulative natural rain and they still exhibited lower DRP and PP concentrations than the controls. These differences were during the third year substantial in terms of percentages but were not statistically significant at the $95 \%$ confidence level.

This research sought to assess how long a given gypsum application can influence soil P retention. This objective can be approached with the assumption that EC relates directly to the amount of residual soluble gypsum that persists in the soil. Gypsum dissolution elevates the ionic strength of the soil environment and may thus enhance particle flocculation, aggregate stability and $\mathrm{P}$ adhesion to the soil particle surfaces. In areas of high rainfall however, soluble compounds are gradually removed by percolation water, returning the soil towards its original state. The pace of this process is partly determined by annual rainfall as well as runoff and percolation volumes, and the inherent solubility of gypsum in water. The effective lifetime of a gypsum amendment likely also varies with soil chemical and physical properties. Both forms of $\mathrm{P}$ analysed in this study appear to follow a curvilinear or split-line relationship when plotted against EC measured in percolation water (Fig. 4). As long as the EC was above 300-400 $\mu \mathrm{S} \mathrm{cm}{ }^{-1}$ in water samples from gypsum amended soils, PP and DRP concentrations were $50 \%$ below corresponding values for the unamended controls. The range of this relationship may be specific to the soils analysed, but the relationship itself is nonetheless significant and merits further consideration especially for different soil types. If the relationship could be generalized to other soils, EC analysis of percolation or tile drainage water would offer a simple means of monitoring the effective lifetime of a given gypsum application.
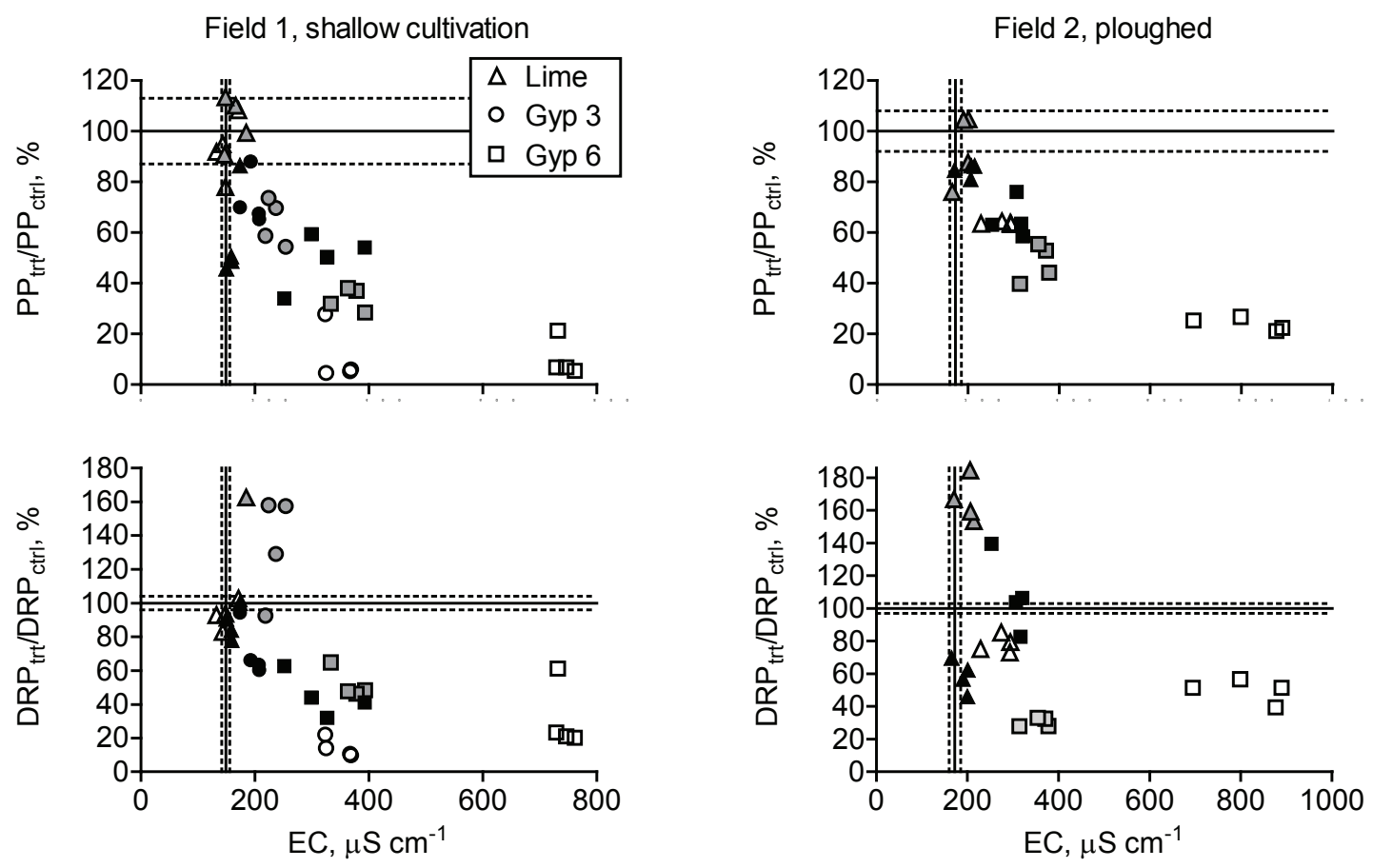

Fig. 4. Concentrations of particulate $P(P P)$ and dissolved reactive $P(D R P)$ plotted against electrical conductivity (EC) measurements of percolation water samples from gypsum and limestone amended soils (markers) relative to values measured from unamended control soils (solid horizontal and vertical lines; dotted lines show the $95 \%$ confidence intervals for control averages). White, grey and black markers indicate the first ( 7 months), second (19 months) and third (31 months) years sampling periods, respectively. The results of all four water samples collected from each stage of the rainfall simulation events (at times $0 . . .3$, as in Fig. 1) are shown. 
We attributed the enhanced $\mathrm{P}$ retention in the soils analysed to two possible mechanisms: (i) retention due to elevated ionic strength of the soil and (ii) precipitation of Ca-phosphate minerals. These mechanisms are not mutually exclusive but generally carry different practical implications. In their discussion of ionic strength in soils, Ryden and Syers (1975) state that rather than simply causing an absolute increase in retention capacity, ionic strength affects the rate at which equilibrium $\mathrm{P}$ sorption is approached. The decrease in DRP concentration observed in percolation water samples of increased ionic strength suggests a shift in the solid-phase $\mathrm{P}$-solution $\mathrm{P}$ equilibrium state towards the surface-adsorbed pool. An increase in ionic strength therefore may simply enhance utilization of the existing lodging sites for ions with high sorption affinities, rather than create new $\mathrm{P}$ retention sites. The second mechanism, Ca-P precipitation, would also initially increase $\mathrm{P}$ retention capacity because Ca-P precipitates would not utilize existing retention sites on metal oxide surfaces but provide an additional P sink. Crystalline Caphosphate phases would first stabilize $\mathrm{P}$ and then gradually (at least partly) re-dissolve as the chemistry of soil solution returns to its initial state prior to the gypsum application.

The ability of Ca-P precipitates to crystallize in significant amounts in such a soil environment that prevailed in our study material is debateable. E.g. Zhu and Alva (1994) hypothesized that Ca-P precipitates were formed in soils of a citrus orchard ( $\mathrm{pH}$ 7.4) following a gypsum amendment. Equilibration tests that these authors conducted with synthetic P-spiked solutions (without the soil component) demonstrated that $\mathrm{P}$ and $\mathrm{Ca}^{2+}$ concentrations decreased in the solution as a result of Ca-P precipitation when the initial $\mathrm{pH}$ was 7.5. At an initial solution $\mathrm{pH}$ of 6.5 and $\mathrm{P}$ concentration of $8 \mathrm{mg} \mathrm{l}^{-1}(0.26 \mathrm{mM}$; the lowest P concentration used by Zhu and Alva 1994) however, all of the added $\mathrm{P}$ remained in the aqueous phase (non-precipitated). Laboratory experiments by Cao et al. (2007) induced Ca-P precipitation in prepared solutions at $\mathrm{pH} 7.1$ with high $\mathrm{Ca}$ and $\mathrm{P}$ concentrations. The system reached the maturation stage of crystal growth (when solution concentrations of $\mathrm{P}$ and $\mathrm{Ca}$ change slowly, if at all) after some hours, at which point $P$ and $C$ a concentrations had decreased to about 15 and $40 \mathrm{mg} \mathrm{l}^{-1}(0.5$ and $1 \mathrm{mM})$, respectively. Because Ca-P precipitates had already formed, the system contained seed crystals. Cao et al. (2007) eventually measured about $85 \%$ conversion of the original dissolved $\mathrm{P}$ to Ca-P precipitates, but the final $\mathrm{P}$ concentrations of the solution phase (about $15 \mathrm{mg} \mathrm{l}^{-1}$ ) were nevertheless high compared to typical soluble $\mathrm{P}$ concentrations in our soils.

Wang et al. (1995) did not detect crystalline Ca-P precipitates in soils collected from dairy holding areas that were supersaturated with respect to both $\mathrm{Ca}$ and $\mathrm{P}$. Leachates from these soils contained 45-79 $\mathrm{mg} \mathrm{l}^{-1} \mathrm{P}, 191-213 \mathrm{mg}$ $\mathrm{I}^{-1} \mathrm{Ca}$ and had $\mathrm{pH}$ values of 7.6-9.0. Stout et al. (2003) found that in soils with high levels of exchangeable acidity, gypsum application apparently drives soluble $\mathrm{P}$ into the metal hydroxide-associated pool, whereas in soils that have a low exchangeable acidity gypsum application may increase acid-extractable $P$ assumed to represent the more stable Ca-P associations, such as hydroxyapatite (Stout et al. 2003). The variable behaviour of soils with contrasting levels of exchangeable acidity may be because of gypsum application brings about polymerization of exchangeable Al as insoluble residues as discussed by Pavan et al. (1984). In their study of an acidic Brazilian Oxisol Pavan et al. (1984) found that a gypsum amendment caused a decrease in concentrations of exchangeable Al found in subsoil components of soil columns, but only a small fraction of exchangeable Al (3\%) was lost to leachate. Most of the Al originally present as exchangeable cations polymerized and remained within the soil profile. Such Al precipitates could serve as an effective sink for $P$ and increase the metal-oxide associated P pool in soils, but significant amounts of Al precipitates are likely to form in acidic soils only.

The extent of Ca-P formation is affected by soluble constituents of the soil solution. Cao et al. (2007) showed that a $\mathrm{SO}_{4}-\mathrm{S}$ concentration of $160 \mathrm{mg} \mathrm{l}^{-1}\left(5 \mathrm{mM} \mathrm{SO}_{4}{ }^{2-}\right)$ had a small inhibitory effect ( $20 \%$ decrease in precipitation rate constant) on the initial Ca-P precipitate formation, but $\mathrm{SO}_{4}{ }^{2-}$ did not ultimately affect the final mass of Ca-P precipitated. Humic acid and $\mathrm{Mg}^{2+}$ were found to block Ca-P crystal formation through $\mathrm{Mg}^{2+}$ substitution for $\mathrm{Ca}^{2+}$ in the crystal lattice, and humic acid through occupation on developing crystal surface. Both $\mathrm{Mg}^{2+}$ and DOC were present in soil solutions and percolation water in our study, albeit in lower concentration than those added in the study of Cao et al. (2007). Whether or not $\mathrm{Mg}^{2+}$ and/or DOC concentrations were high enough to inhibit Ca-P precipitation in our soils remains an open question.

Similar to turbidity and PP, DOC concentrations in water samples from soils subjected to the gypsum amendments exhibited lower concentrations than those measured in water samples from the unamended control and limestone amended soils. Organic carbon in soils is partly associated with the mineral matrix, occurring as coatings on soil aggregates, adsorbed films on mineral surfaces, separate organic aggregates, and dissolved components of the soil solution. An increase in the ionic strength of a soil solution can increase the adsorption of organic molecules in a manner similar to which it affects $\mathrm{P}$ sorption. An increase in $\mathrm{Ca}^{2+}$ concentration may also stabilize organic aggregates by substituting $\mathrm{Ca}^{2+}$ for a singly charged ion (i.e., $\mathrm{H}^{+}$or $\mathrm{K}^{+}$) at negatively charged side groups (i.e., $\mathrm{R}-\mathrm{COO}-$ ). Calcium ions can also potentially promote cation bridging between separate molecules (e.g. R-COO-Ca-OOC-R) and 
provide structural support to larger organic aggregates. Stabilization of dissolved organic matter in Ca-saturated soils was demonstrated by Römkens et al. (1996) in their study of DOC solubility in four Dutch soils (three agricultural, and one forest soil). The variables analysed in their study included $\mathrm{pH}$, cation composition of the background electrolyte solution ( $\mathrm{Na}^{+}$or $\mathrm{Ca}^{2+}$ ), and $\mathrm{Ca}^{2+}$ activity in the solution phase. Römkens et al. (1996) found that $\mathrm{NaCl}$ and deionized water extracted equal amounts of $\mathrm{DOC}$ from the soils and an increase in $\mathrm{pH}$ from about 2 to 8 doubled the amount of soluble DOC. Using $\mathrm{CaCl}_{2}$ (at equal ionic strength as the $\mathrm{NaCl}$ ) to extract DOC showed no such $\mathrm{pH}$ dependence, with $\mathrm{DOC}$ concentrations similar at all $\mathrm{pH}$ values. The authors also observed a constant, linear decrease in solution-phase DOC with increasing $\mathrm{Ca}^{2+}$ concentration. Lower concentration of DOC translates to lower oxygen demand in surface waters suggesting that gypsum amendments may benefit water quality also in this respect. Muneer and Oades (1989) also showed that gypsum amendments stabilize soil organic matter by slowing organic matter breakdown to small, more mobile DOC species, thus reducing carbon mineralization to $\mathrm{CO}_{2}$.

An increase in the leaching of $\mathrm{K}^{+}$and $\mathrm{Mg}^{2+}$ ions is a consequence of the elevated concentration of $\mathrm{Ca}^{2+}$ ions in soil solution associated with gypsum dissolution. Because $\mathrm{Ca}^{2+}$ effectively competes for cation exchange sites (surfaces of negatively charged clay minerals and reactive functional groups on organic molecules), other cations are displaced into the soil solution where they can be removed by water flow. In this study, $\mathrm{K}^{+}$concentrations of percolation water from the gypsum-amended soils were initially about twice as high as those observed in water samples from unamended controls and limestone amended soils. The apparent mobilization of $\mathrm{Mg}^{2+}$ from gypsum amended soils was even more substantial, as evident from the 3-5 fold increase in $\mathrm{Mg}^{2+}$ concentrations relative to those observed in water samples from the unamended controls and limestone amended soils. Repeated gypsum applications may thus change the cation composition of soils over the long term, potentially necessitating compensation for $\mathrm{K}^{+}$and $\mathrm{Mg}^{2+}$ loss through fertilization. While increased $\mathrm{Ca}^{2+}$ saturation improves soil structure, plants need a balanced supply of nutrients at all times. Pavan et al. (1984) discussed $\mathrm{Mg}^{2+}$ deficiency in an acidic $(\mathrm{pH} 4-5)$ Brazilian Oxisol as a result of a gypsum application. These workers reported increased leaching of $\mathrm{Mg}^{2+}$ through meter-scale soil columns, and an $80 \%$ decrease in exchangeable $\mathrm{Mg}^{2+}$ content of the topsoil (0-20 $\mathrm{cm}$ depth; relative to the control) after 6 months of irrigation. Ekholm et al. (2012) however did not find consistent changes in exchangeable $\mathrm{Mg}^{2+}$ and $\mathrm{K}^{+}$in gypsum amended soils in a field area similar to that analysed here.

\section{Conclusions}

Water samples from gypsum amended soils showed significant reductions in concentrations of suspended soil matter and of PP, DRP, DOC and $\mathrm{N}_{\text {org }}$. These effects were most pronounced after the first winter and spring following the application in the previous autumn and were still detectable after three winter periods. Provided that Ca-P precipitates can form in the soil, the long-term effects of gypsum applications on DRP leaching could be significant, but this retention mechanism is somewhat speculative in the soils of our study. Nevertheless, gypsum amendments seems to be a promising technique for erosion control and retention of soil $\mathrm{P}$ in annually tilled clay soils, even though the cost of the treatment likely restricts its use for small areas that have an unproportionally large effect on surface water quality. Monitoring EC of drainage flow may provide a simple means of assessing the efficacy and lifetime of a given gypsum amendment, especially in areas requiring continuous erosion mitigation and $\mathrm{P}$ retention in highly P-saturated soils. Repeated gypsum applications may affect nutrient balance in soils, because gypsum increases leaching of other macronutrient cations. This effect may not be especially relevant to clay soils in southern Finland with large reserves of exchangeable $\mathrm{Mg}^{2+}$ and $\mathrm{K}^{2+}$, at least in case of infrequent gypsum applications.

\section{Acknowledgements}

We thank Yara Suomi Oy and the Finnish Funding Agency for Technology and Innovation (TEKES) for funding this research. The work was presented during a workshop organized within COST Action 869 in Jokioinen, Finland. We warmly thank Helena Merkkimiemi for performing laboratory analyses, Taisto Sirén, Aaro Närvänen, Johan Boleij and Vesa Niemi for help in conducting rainfall simulations, and Matti Ylösmäki, Marja-Liisa Westerlund, and Ilkka Sarikka for assistance in soil monolith coring and other tasks. 


\section{References}

Anderson, D.L., Tuovinen, O.H., Faber, A. \& Ostrokowski, I. 1995. Use of soil amendments to reduce soluble phosphorus in dairy soils. Ecological Engineering 5: 229-246.

Bar-Yosef, B., Kafkafi, U., Rosenberg, R. \& Sposito, G. 1988. Phosphorus adsorption by kaolinite and montmorillonite: I. Effect of time, ionic strength, and pH. Soil Science Society of America Journal 52: 1580-1585.

Cao, X., Harris, W.G., Josan, M.S. \& Nair, V.D. 2007. Inhibition of calcium phosphate precipitation under environmentally-relevant conditions. Science of the Total Environment 383: 205-215.

Coale, F.J., Porter, P.S. \& Davis, W. 1994. Soil amendments for reducing phosphorus concentration in drainage water from Histosols. Soil Science Society of America Journal 58: 1470-1475.

Cox, J.W., Varcoe, J., Chittleborough, D.J. \& van Leeuwen, J. 2005. Using gypsum to reduce phosphorus in runoff from subcatchements in South Australia. Journal of Environmental Quality 34: 2118-2128.

Ekholm P., Valkama, P., Jaakkola, E., Kiirikki, M., Lahti, K. \& Pietola, L. 2012. Gypsum amendment of soils reduces phosphorus losses in an agricultural catchment. Agricultural and Food Science 21: 279-291.

Favaretto, N., Norton, L.D., Joern, B.C. \& Brouder, S.M. 2006. Gypsum amendment and exchangeable calcium and magnesium affecting phosphorus and nitrogen in runoff. Soil Science Society of America Journal 70: 1788-1796.

Grasso, D., Subramaniam, K., Butkus, M., Strevett, K. \& Bergendahl, J. 2002. A review of non-DLVO interactions in environmental colloidal systems. Reviews in Environmental Science and Biotechnology 1: 17-38.

Iho, A. \& Laukkanen, M. 2012. Gypsum amendment as a means to reduce agricultural phosphorus loading: an economic appraisal. Agricultural and Food Science 21: 307-324.

IUSS Working Group WRB. 2006. World reference base for soil resources 2006. World Soil Resources Reports No. 103. Food and Agriculture Organization of the United Nations, Rome, Italy.

Jaakkola, E., Tattari, S., Ekholm, P., Pietola, L., Posch, M. \& Bärlund, I. 2012. Simulated effects of gypsum amendment on phosphorus losses from agricultural soils. Agricultural and Food Science 21: 292-306.

Karhunen, J. \& Vermeulen, S. 2000. Natural radioactivity of phosphates and phosphogypsum. Fertilizer International 378: 75-81.

Kuusisto, E. 1980. On the intensity of rainfall in Finland. Aqua Fennica 10: 3-11.

Miller, W.P. 1987. Infiltration and soil loss of three gypsum-amended Ultisols under simulated rainfall. Soil Science Society of America Journal 51: 1314-1320.

Muneer, M. \& Oades, J.M. 1989. The role of Ca-organic interactions in soil aggregate stability .II. Field studies with 14C-labeled straw, $\mathrm{CaCO} 3$ and CaSO4×2 H2O. Australian Journal of Soil Research 27: 401-409.

O'Connor, G.A., Brinton, S. \& Silveira, M.L. 2005. Evaluation and selection of soil amendments for field testing to reduce P losses. Soil and Crop Society of Florida Proceedings 64: 22-34.

Pavan, M.A., Bingham, F.T. \& Pratt, P.F. 1984. Redistribution of exchangeable calcium, magnsium, and aluminum following lime or gypsum applications to a Brazilian Oxisol. Soil Science Society of America Journal 48: 33-38.

Persson, L. \& Bergströn, L. 1991. Drilling method for collection of undisturbed soil monoliths. Soil Science Society of America Journal 55: 285-287.

Römkens, P.F., Bril, J. \& Salomons, W. 1996. Interaction between $\mathrm{Ca}^{2+}$ and dissolved organic carbon: implications for metal mobilization. Applied Geochemistry 11: 109-115.

Ryan, J.N. \& Elimelech, M. 1996. Colloid mobilization and transport in groundwater. Colloids and Surfaces A: Physicochemical and Engineering Aspects 107: 1-56.

Ryden, J.C. \& Syers, J.K. 1975. Rationalization of ionic strength and cation effects on phosphate sorption by soils. Journal of Soil Science 26: 395-406.

Salles, C., Poesen, J. and Sempere-Torres, D. 2002. Kinetic energy of rain and its functional relationship with intensity. Journal of Hydrology 257: 256-270.

Shainberg, I., Sumner, M.E., Miller, W.P., Farina, M.P.W., Pavan, M.A. \& Fey, M.V. 1989. Use of gypsum in soils: A review. In: Stewart, B.A. (ed.). Advances in Soil Science 9. New York: Springer Verlag, Inc. p. 1-111.

Stout, W.L., Sharpley, A.N. \& Landa, J. 2000. Effectiveness of coal combustion by-products in controlling phosphorus export from soils. Journal of Environmental Quality 29: 1239-1244.

Stout, W.L., Sharpley, A.N. \& Weaver, S.R. 2003. Effect of amending high phosphorus soils with flue gas desulfurization gypsum on plant uptake and soil fractions of phosphorus. Nutrient Cycling in Agroecosystems 67: 21-29.

Turtola, E., Alakukku, L., Uusitalo, R. \& Kaseva, A. 2007. Surface runoff, subsurface drainflow and soil erosion as affected by tillage in a clayey Finnish soil. Agricultural and Food Science 16: 332-351.

Uusitalo, R. \& Aura, E. 2005. A rainfall simulation study on the relationships between soil test P versus dissolved and potentially bioavailable particulate phosphorus forms in runoff. Agricultural and Food Science 14: 335-345.

Uusitalo, R., Turtola, E. \& Lemola, R. 2007. Phosphorus losses from a subdrained clayey soil as affected by cultivation practices. Agricultural and Food Science 16: 352-365.

Venäläinen, A., Jylhä, K., Kilpeläinen, T., Saku, S., Tuomenvirta, H., Vajda, A. \& Ruosteenoja, K. 2009. Recurrence of heavy precipitation, dry spells and deep snow cover in Finland based on observations. Boreal Environment Research 14: 166-172.

Vuorinen, J. \& Mäkitie, O. 1955. The method of soil testing in use in Finland. Agrogeological Publications 63: 1-44. 
Wang, H.D., Harris, W.G., Reddy, K.R. \& Flaig, E.G. 1995. Stability of phosphorus forms in dairy-impacted soils under simulated leaching. Ecological Engineering 5: 209-227.

Warrington, D., Shainberg, I., Agassi, M. \& Morin, J. 1989. Slope and phosphogypsum's effects on runoff and erosion. Soil Science Society of America Journal 53: 1201-1205.

Watts, D.B. \& Torbert, H.A. 2009. Impact of gypsum applied to grass buffer strips on reducing soluble P in surface water runoff. Journal of Environmental Quality 38: 1511-1517.

Zhu, B. \& Alva, A.K. 1994. The effect of gypsum amendment on transport of phosphorus in a sandy soil. Water, Air and Soil Pollution 78: $375-382$ 